\title{
Chronic Wasting Disease-Research by the U.S. Geological Survey and Partners
}

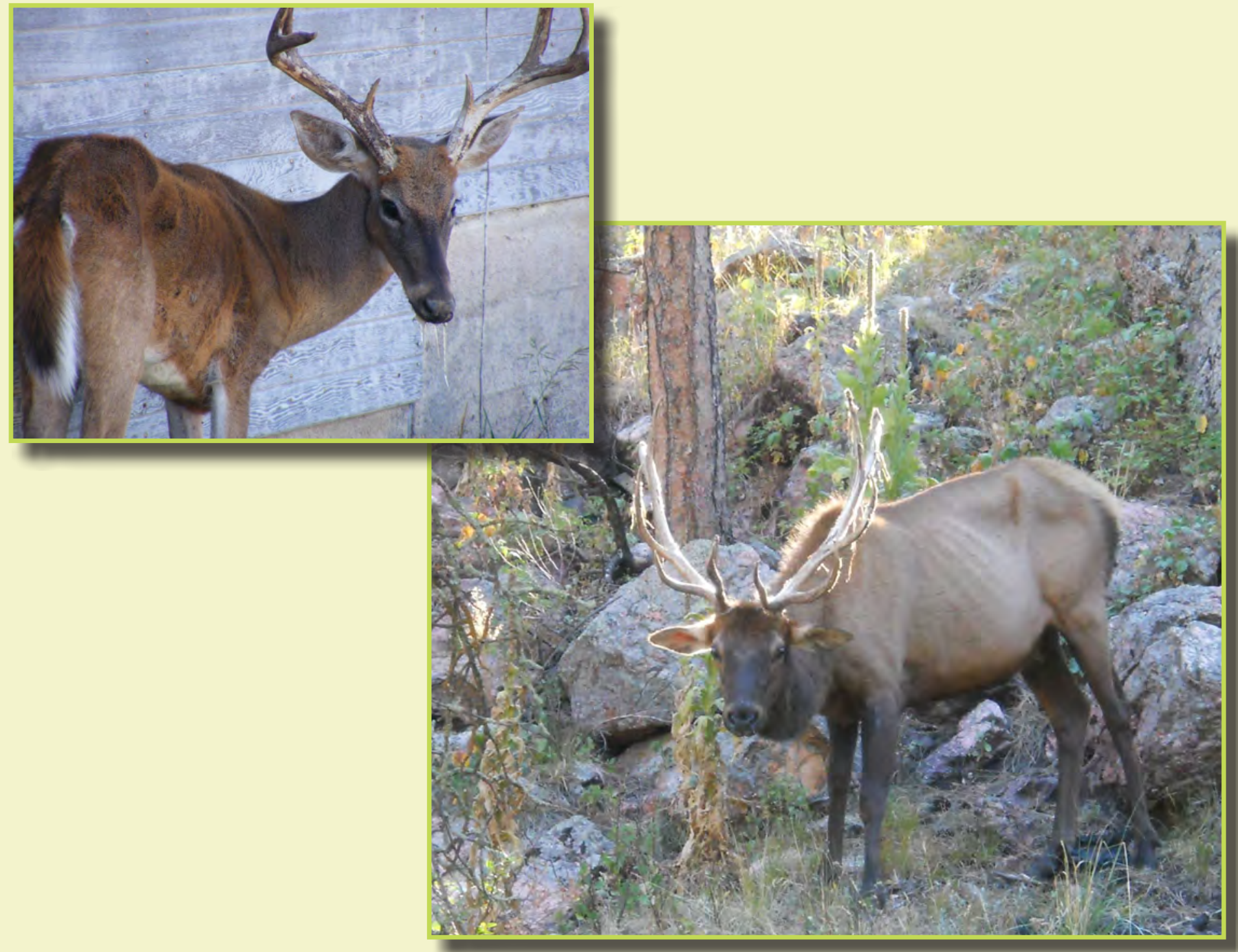

Open-File Report 2019-1109

Version 2.0, November 2019 
Cover photo (Top Left): White-tailed deer infected with chronic wasting disease showing significant weight loss. Photograph by Warden Micheal Hopper, Kansas Department of Wildlife, Parks and Tourism; used with permission from the Kansas Department of Wildlife; https://ksoutdoors.com/.

(Bottom Right): Elk infected with chronic wasting disease showing significant weight loss. Photograph by the National Park Service. 


\section{Chronic Wasting Disease-Research by the U.S. Geological Survey and Partners}

By M. Camille Hopkins, Christina M. Carlson, Paul C. Cross, Christopher J. Johnson, Bryan J. Richards, Robin E. Russell, Michael D. Samuel, Glen A. Sargeant, Daniel P. Walsh, and W. David Walter

Open-File Report 2019-1109

Version 2.0, November 2019 


\title{
U.S. Department of the Interior DAVID BERNHARDT, Secretary
}

\section{U.S. Geological Survey James F. Reilly II, Director}

\author{
U.S. Geological Survey, Reston, Virginia \\ First release: 2019 \\ Revised: November 2019 (ver. 2.0)
}

For more information on the USGS - the Federal source for science about the Earth, its natural and living resources, natural hazards, and the environment-visit https://www.usgs.gov or call 1-888-ASK-USGS.

For an overview of USGS information products, including maps, imagery, and publications, visit https://store.usgs.gov.

Any use of trade, firm, or product names is for descriptive purposes only and does not imply endorsement by the U.S. Government.

Although this information product, for the most part, is in the public domain, it also may contain copyrighted materials as noted in the text. Permission to reproduce copyrighted items must be secured from the copyright owner.

Suggested citation:

Hopkins, M.C., Carlson, C.M., Cross, P.C., Johnson, C.J., Richards, B.J., Russell, R.E., Samuel, M.D., Sargeant, G.A., Walsh, D.P., and Walter, W.D., 2019, Chronic wasting disease-Research by the U.S. Geological

Survey and partners (ver. 2.0, November 2019): U.S. Geological Survey Open-File Report 2019-1109, 29 p., https://doi.org/10.3133/ofr20191109. 


\section{Contents}

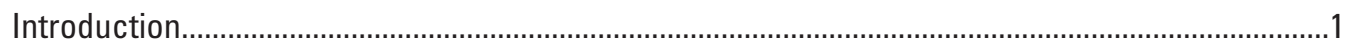

List of Projects Supporting Chronic Wasting Disease Research Goals and Action Items................

Chronic Wasting Disease Ecology and Epidemiology Studies.........................................................

1. Has Chronic Wasting Disease Produced Genetic Selection in Wisconsin White-

Tailed Deer Populations? .................................................................................................

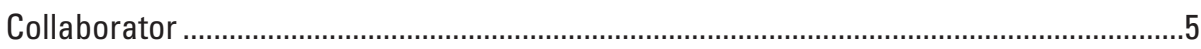

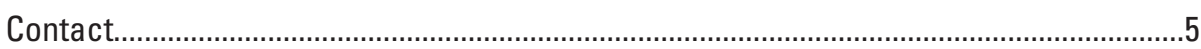

Publications ....................................................................................................

2. Chronic Wasting Disease Shedding Across Cervid Species and Environmental

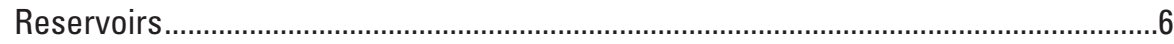

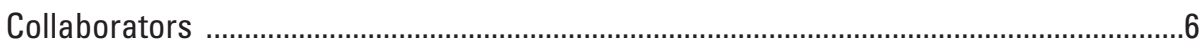

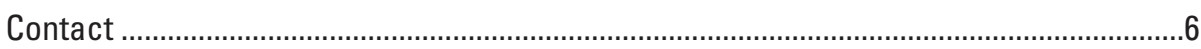

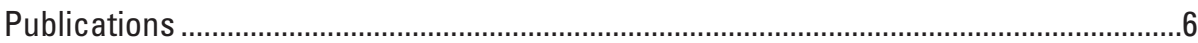

3. The Role of Environmental and Direct Transmission in Chronic Wasting Disease

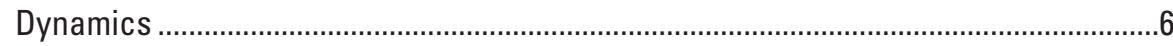

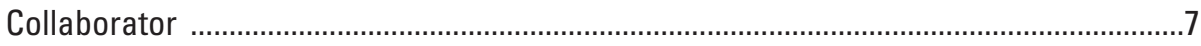

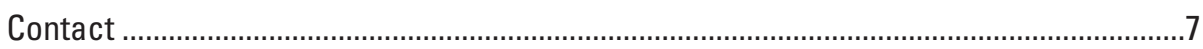

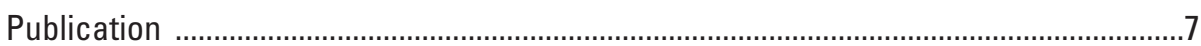

4. Increasing Prevalence of Chronic Wasting Disease and Implications for Elk

Population Management at Wind Cave National Park, South Dakota ...........................7

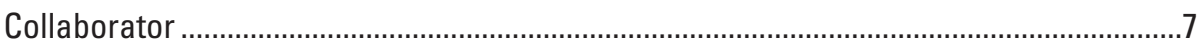

Contact

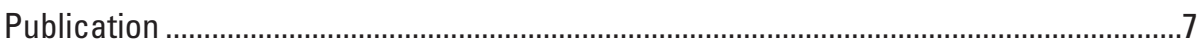

5. Investigating the Genetic Diversity of the Prion Protein Gene Among Subspecies

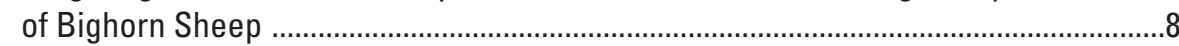

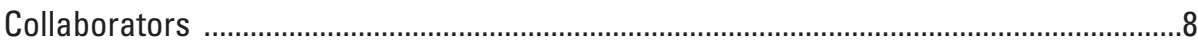

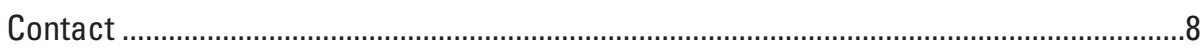

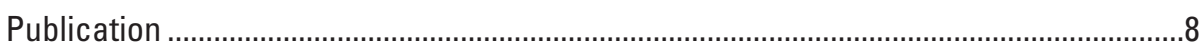

6. Application of Landscape Genetic Techniques to Investigation of Chronic

Wasting Disease Dynamics and Transmission in Wisconsin White-Tailed Deer

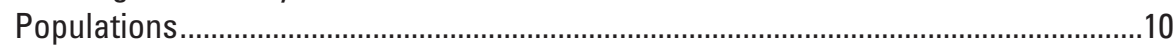

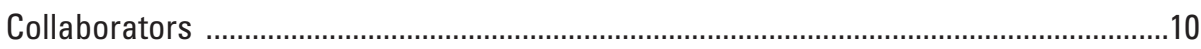

Contact

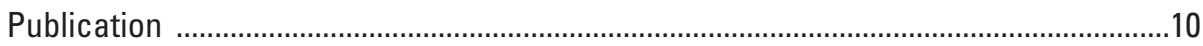

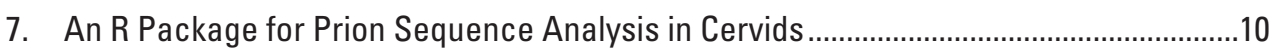

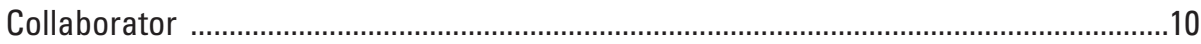

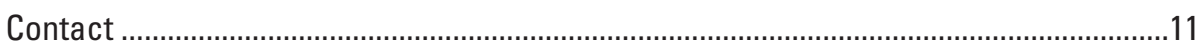

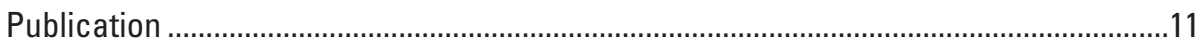

Chronic Wasting Disease Risk Assessment and Modeling Studies ..............................................11

8. Spatial Modeling of Chronic Wasting Disease Epizootiology and Disease

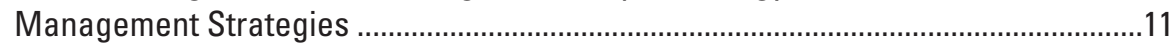

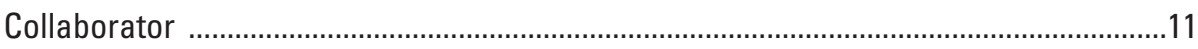

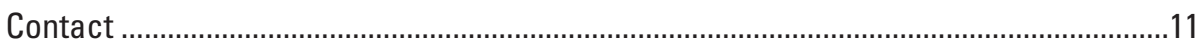

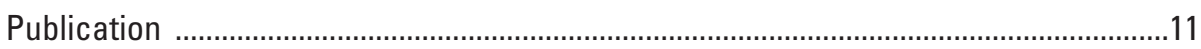


9. Developing a Targeted Mule Deer Chronic Wasting Disease Surveillance

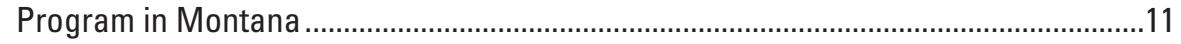

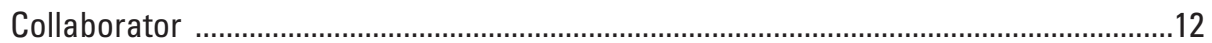

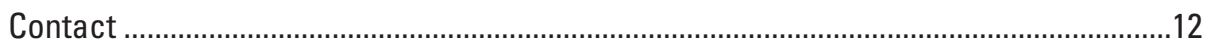

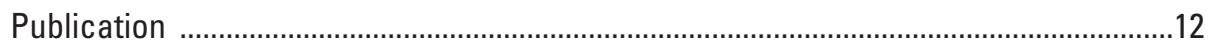

10. When Good Habitats Go Bad: Modeling the Potential for Disease-Induced

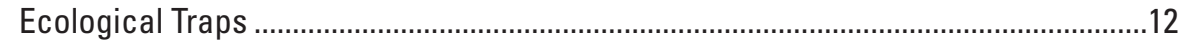

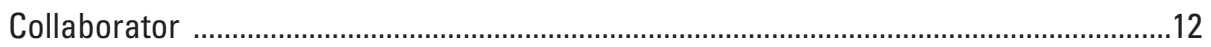

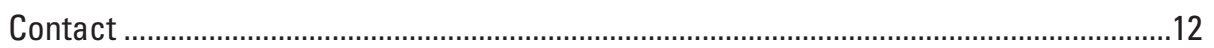

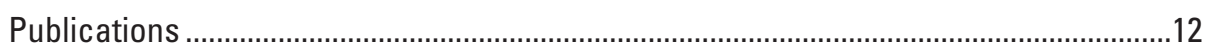

11. Genetic Estimates of Mule Deer Connectivity in Montana ...........................................12

Collaborator

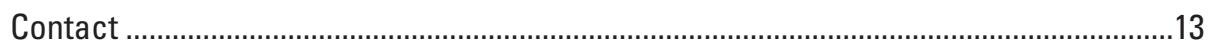

Publications ..............................................................................................................13

12. Elk Connectivity and Current and Potential Disease Movement Across the Greater Yellowstone Ecosystem .............................................................................13

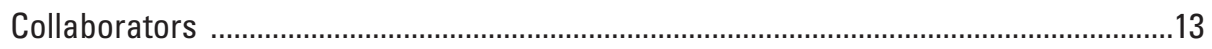

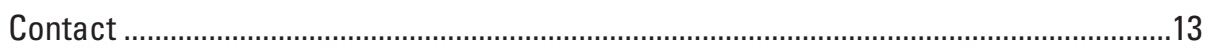

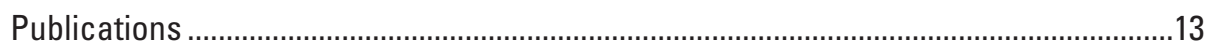

13. Developing and Evaluating Spatial Analytical Techniques for Predictive Modeling of Emerging Diseases of Epidemic Potential ...............................................14

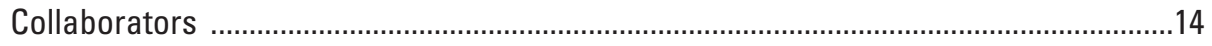

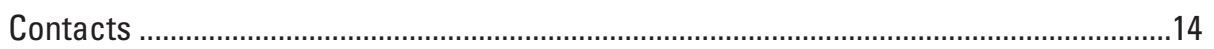

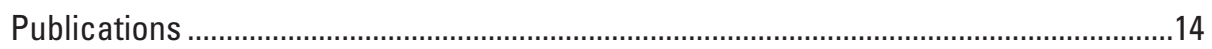

14. Linking Process to Pattern: Estimating Chronic Wasting Disease Dynamics in

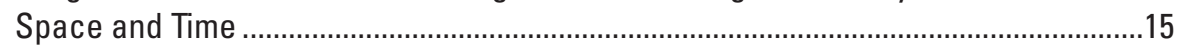

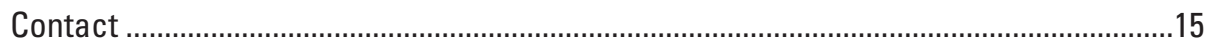

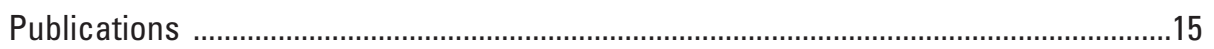

15. Risk Assessment of Captive Cervid Facilities in Pennsylvania: Implications to the Spread of Chronic Wasting Disease .....................................................................

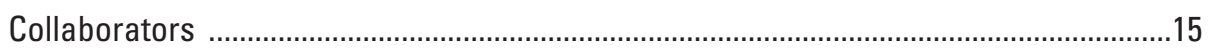

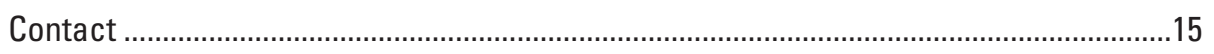

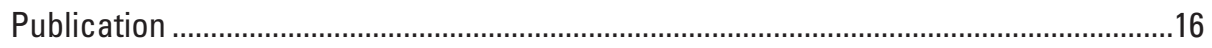

16. Influence of Forested Habitats on Distribution of Chronic Wasting Disease in

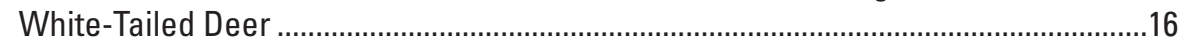

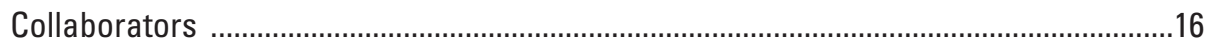

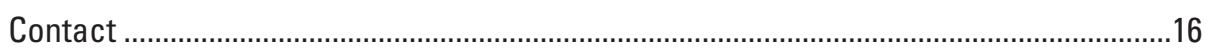

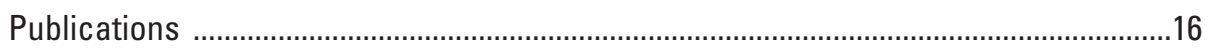

17. Factors Affecting the Risk of Chronic Wasting Disease Infection in Male WhiteTailed Deer: Implications for Managing Chronic Wasting Disease in Wisconsin......17

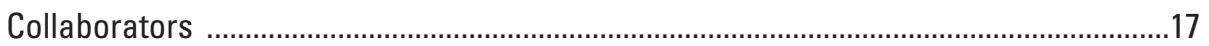

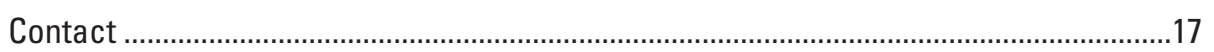

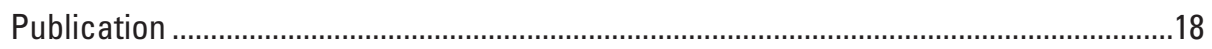

18. Factors Affecting Chronic Wasting Disease Transmission: A Comparison of Chronic Wasting Disease Epizootics in Wisconsin and Illinois....................................18

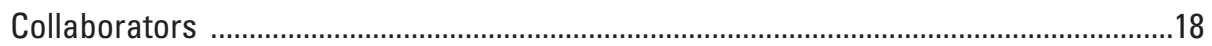

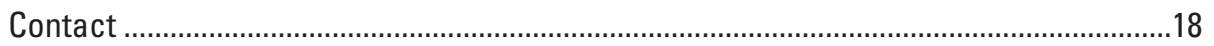




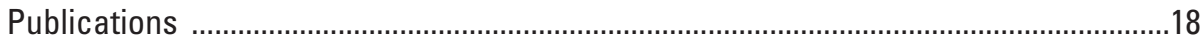

19. Modeling Effects of Environmental Persistence on Potential Deer Declines................19

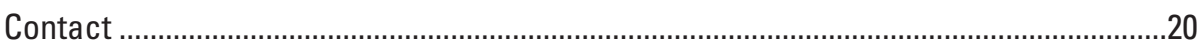

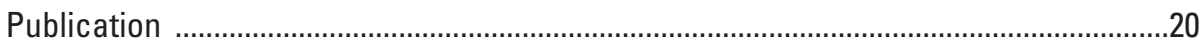

20. Assessing the Risk of Prion Disease Transmission to Bighorn Sheep ...........................20

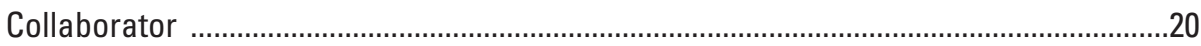

Contact.

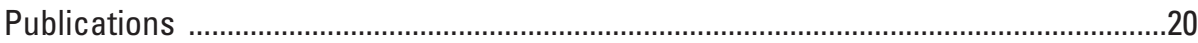

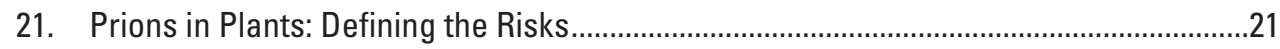

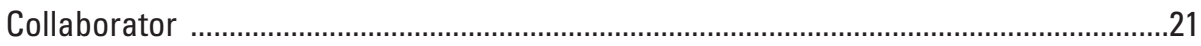

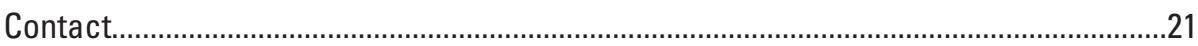

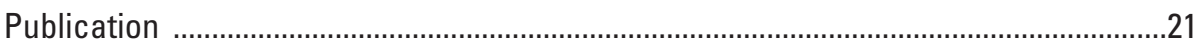

Development of Chronic Wasting Disease Surveillance and Mitigation Tools ...............................21

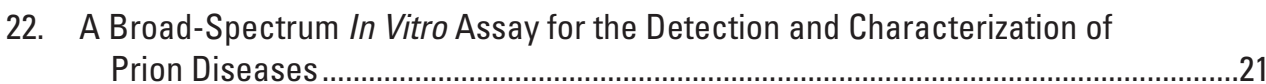

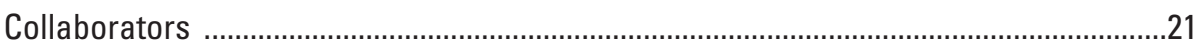

Contact

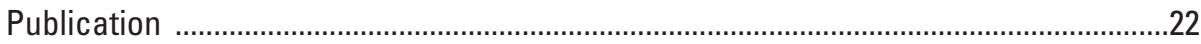

23. Degradation of Prions by a Serine Protease from Lichens ..............................................22

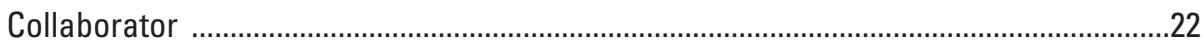

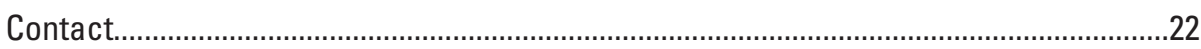

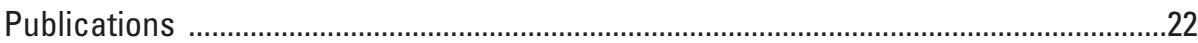

24. Development of Protein Misfolding Cyclic Amplification (PMCA) for Detection of Chronic Wasting Disease Prions in Environmental Samples and Deer Tissues.........22

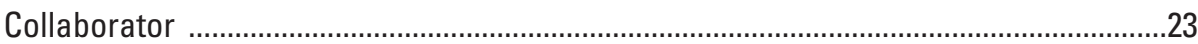

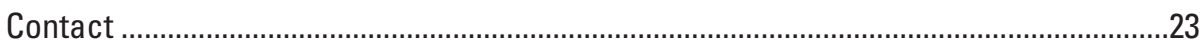

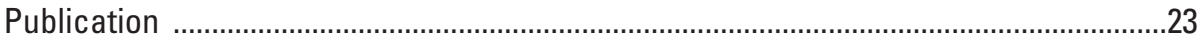

25. Antemortem Detection of Chronic Wasting Disease Prions in Nasal Brush

Collections and Rectal Biopsy Specimens from White-Tailed Deer by Real-

Time Quaking-Induced Conversion ...............................................................................23

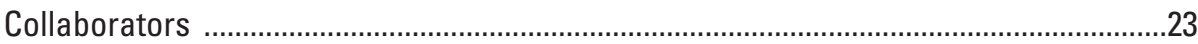

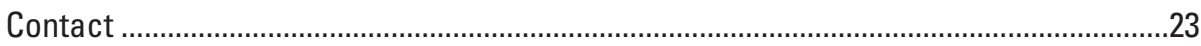

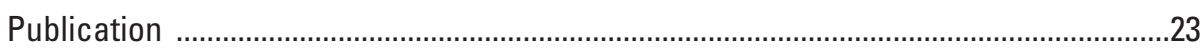

26. Improving Wildlife Disease Surveillance Using Epidemiological Knowledge ................24

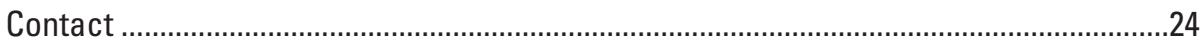

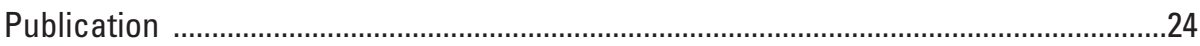

27. Developing a Surveillance System for Early Detection of Chronic Wasting Disease for Shenandoah National Park ...........................................................................24

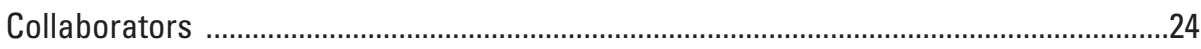

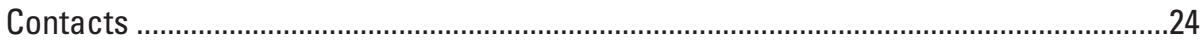

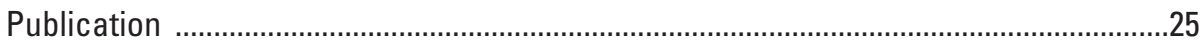

28. Leveraging Expert Knowledge to Improve Surveillance Strategies for Chronic

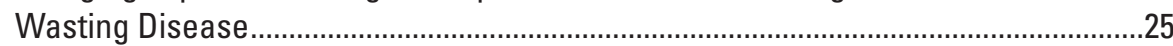

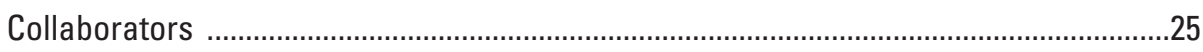

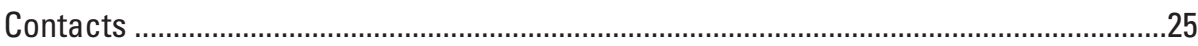

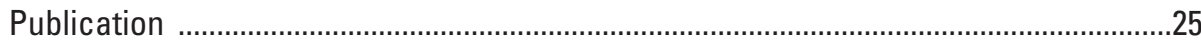


29. Seeded Amplification of Chronic Wasting Disease Prions from Elk by Real-Time Quaking-Induced Conversion.......................................................................................25

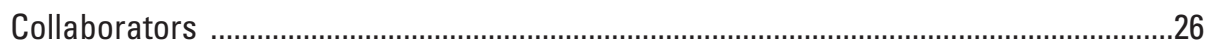

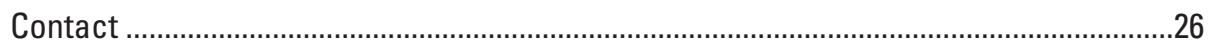

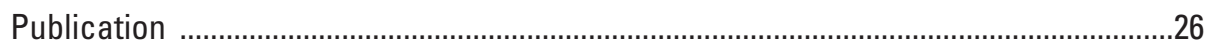

30. Assessment of White-Tailed Deer Genetic Structure to Determine Potential Disease Transmission Pathways and Population Susceptibility to Chronic

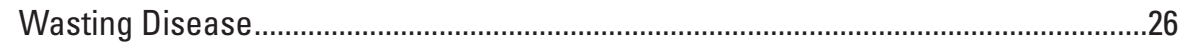

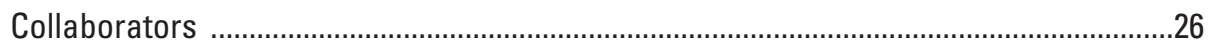

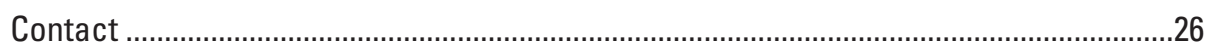

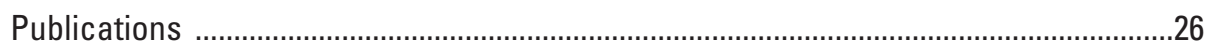

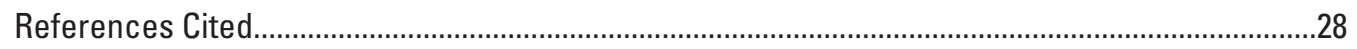

\section{Figures}

1. Photograph of a white-tailed deer infected with chronic wasting disease showing significant weight loss...

2. Photograph of an elk infected with chronic wasting disease showing significant weight loss...

3. Map of the western half of the United States and Canada showing the range of bighorn sheep in 2013 overlaps the occurrence of domestic sheep scrapie and chronic wasting disease

4. Map showing the study area in the central Appalachian region of the northeastern United States..

5. Graph showing that the proportion of the force of infection due to indirect transmission increases over time and varies with respect to prion survival

6. Map showing the distribution of white-tailed deer genetic clusters in Pennsylvania, Maryland, and Virginia in the Mid-Atlantic region of the Unites States .27

\section{Table}

1. List of U.S. Geological Survey research projects highlighted in this report that are organized by three research categories: (1) CWD Ecology and Epidemiology Studies, (2) CWD Risk Assessment and Modeling Studies, and (3) Development of CWD Surveillance and Mitigation Tools. 


\section{Conversion Factors}

U.S. customary units to International System of Units

\begin{tabular}{rrr}
\hline Multiply & By & To obtain \\
\hline & Length & \\
\hline mile (mi) & 1.609 & kilometer $(\mathrm{km})$ \\
\hline
\end{tabular}

International System of Units to U.S. customary units

\begin{tabular}{ccl}
\hline Multiply & By & To obtain \\
\hline \multicolumn{3}{c}{ Area } \\
\hline square kilometer $\left(\mathrm{km}^{2}\right)$ & 247.1 & acre \\
\hline \multicolumn{3}{c}{ Mass } \\
\hline gram $(\mathrm{g})$ & 0.03527 & ounce, avoirdupois $(\mathrm{oz})$ \\
\hline
\end{tabular}

\section{Abbreviations}

CWD

chronic wasting disease

PMCA protein misfolding cyclic amplification

PRNP prion protein gene

PrPcwo chronic wasting disease-associated prion protein

USGS U.S. Geological Survey 


\title{
Chronic Wasting Disease-Research by the U.S. Geological Survey and Partners
}

\author{
By M. Camille Hopkins, Christina M. Carlson, Paul C. Cross, Christopher J. Johnson, Bryan J. Richards,
} Robin E. Russell, Michael D. Samuel, Glen A. Sargeant, Daniel P. Walsh, and W. David Walter

\section{Introduction}

Chronic wasting disease (CWD) is the only transmissible spongiform encephalopathy, a class of invariably fatal neurodegenerative mammalian diseases associated with a misfolded cellular prion protein (Williams and Young, 1980; Prusiner, 1982) found in wild free-ranging animals. Because it has a long incubation period, affected animals in Cervidae (the deer family; referred to as "cervids") may not show signs of disease for several years. While signs are not specific to CWD, affected cervids (deer, elk, moose, and reindeer) show changes in appearance (such as progressive weight loss, figs. 1 and 2) and changes in behavior such as stumbling, tremors, and teeth grinding. CWD can be transmitted by direct contact or through a contaminated environment. The causative prion agent is highly resistant to degradation.

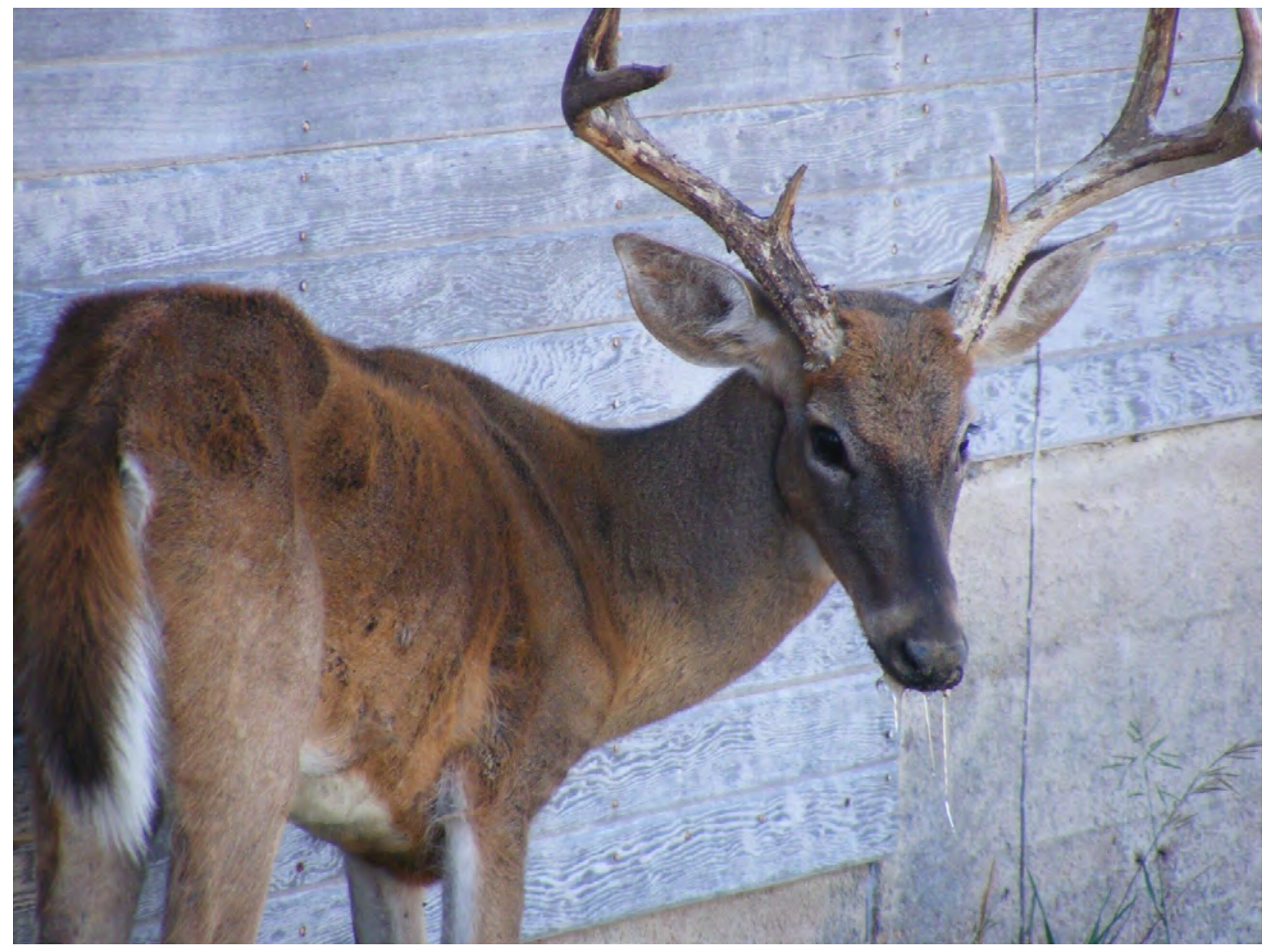

Figure 1. White-tailed deer infected with chronic wasting disease showing significant weight loss. Photograph by Warden Micheal Hopper, Kansas Department of Wildlife, Parks and Tourism; used with permission from the Kansas Department of Wildlife; https:// ksoutdoors.com/. 


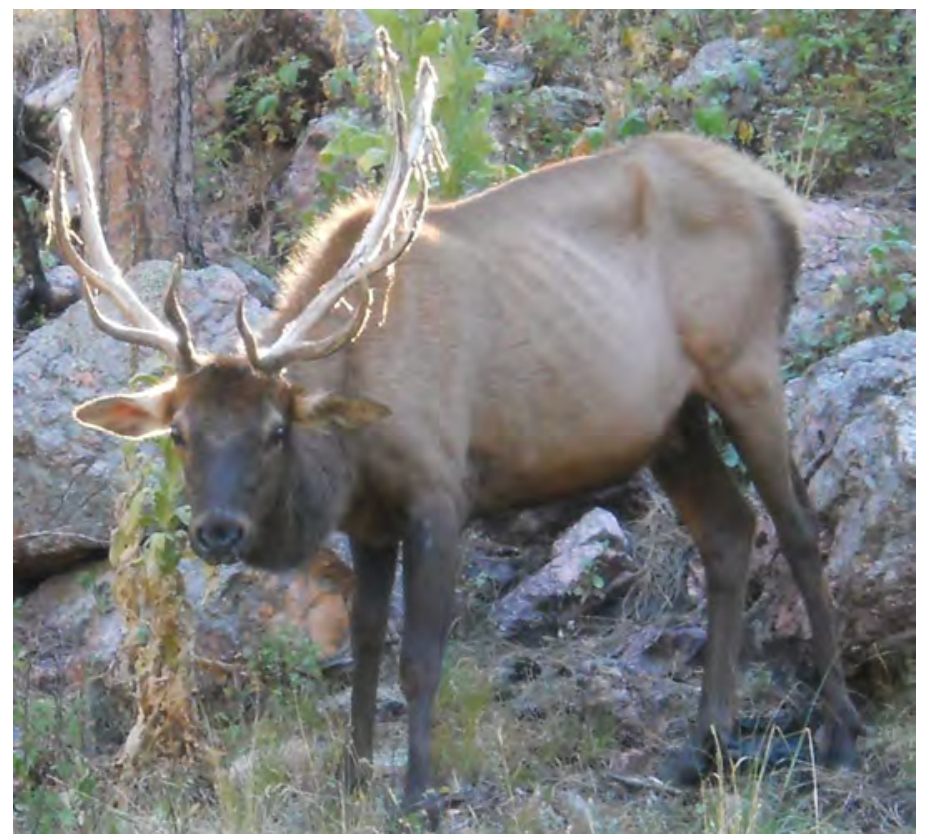

Figure 2. Elk infected with chronic wasting disease showing significant weight loss. Photograph by the National Park Service.
In recent decades, CWD has transitioned from a novel, obscure prion disease of cervids with limited geographical distribution, to a disease that poses substantial ecological, agricultural, and economic risks across large regions of North America. Since its discovery in free-ranging elk and deer populations in the western United States in the 1980s, CWD has been reported in captive or free-ranging cervid populations in 26 States, 3 Canadian Provinces, the Republic of South Korea (Sohn and others, 2002; Kim and others, 2005; U.S. Geological Survey, 2016), Finland (Finnish Food Authority, 2019), Sweden (National Veterinary Institute, 2019), and Norway (Benestad and others, 2016). In addition, the proportion of CWD-infected animals is increasing in many areas where the disease is already established. For example, the proportion of CWD-positive adult male and female white-tailed deer in north-central Iowa County, Wisconsin, has more than doubled during a 6-year period (2011-16). Approximately 40-50 percent of the adult male population and 20-30 percent of the adult female population was infected by 2016, making north-central Iowa County one of the most heavily affected regions in the United States (Wisconsin Department of Natural Resources, 2019). In some heavily affected areas, total cervid numbers have decreased over time due to CWD,

which suggests that these cervid populations may not be sustainable in the long-term. In east-central Wyoming, the number of wild white-tailed deer in a study population declined 10.4 percent annually between 2003 and 2010. Moreover, CWD-positive deer were 4.5 times more likely to die each year than deer that tested negative (Edmunds and others, 2016).

Outbreaks and sustained epizootics of CWD can have substantial economic impacts on wildlife management, hunting, tourism, and cervid farming. As one example, the Wisconsin Department of Natural Resources spent 32.3 million dollars on CWD surveillance and management from 2001 to 2006 (Wisconsin Legislative Audit Bureau, 2006). Long-term effects of CWD on cervid populations and ecosystems remain unclear, and control or eradication of CWD, once established in free-ranging cervid populations, has been largely ineffective (Gillin and Mawdsley, 2018). Additional scientific knowledge is needed to better understand CWD risks and transmission dynamics, to forecast short- and long-term impacts of the disease, and to implement effective management strategies for prevention and control.

U.S. Geological Survey (USGS) research on CWD aligns with two research goals and an action item in the interagency North American Plan (Chronic Wasting Disease Task Force, 2002, p. [9]) as quoted below:

- Goal 1-Rapid Diagnostics: There is an urgent need for research to establish rapid diagnostic techniques in live animals, carcasses, and environmental samples.

- Goal 3-Management and Ecology of the Disease and the Host: There is a need to understand the interactions between host species ecology and CWD dynamics, and the implication of these interactions for disease management.

- Action item 3-Conduct research into disease management and host ecology. Prioritized needs include: 1) developing and enhancing models of CWD dynamics; . . . .

The USGS CWD research conducted at science centers and cooperative research units (CRUs) is supporting these research goals and action items through three focal research categories (1-3 below, table 1) that are highlighted in this report. These categories were chosen based on capabilities of USGS scientists that would support CWD management. The three focal research categories include:

- CWD Ecology and Epidemiology Studies_-Understanding the ecology of CWD, including impacts on populations and communities and its implications for disease management;

- CWD Risk Assessment and Modeling Studies-Assessing the risk of CWD spread and persistence in wildlife and the environment; and 
- Development of CWD Surveillance and Mitigation Tools—Developing tools for early detection, diagnosis, surveillance, and control of CWD.

\section{List of Projects Supporting Chronic Wasting Disease Research Goals and Action Items}

The USGS, the science bureau of the Department of the Interior, conducts wildlife disease surveillance and research to support management of affected species and their habitats. The scientific information is relevant to governmental agencies that manage wildlife and their habitats including the U.S. Fish and Wildlife Service, the National Park Service, the U.S. Department of Agriculture, and other Federal, State, and tribal agencies as well as conservation partners (non-governmental organizations, businesses, and private landowners). Each project description in this report (1-30) includes the non-USGS collaborators (Federal, State, tribal agencies, and universities) and a USGS point of contact (principal investigator). If there are USGS publications associated with the project, a publication list is provided at the end of each project description. Non-USGS citations are listed at the end of the report in the References Cited section.

Table 1. List of U.S. Geological Survey research projects highlighted in this report that are organized by three research categories: (1) CWD Ecology and Epidemiology Studies, (2) CWD Risk Assessment and Modeling Studies, and (3) Development of CWD Surveillance and Mitigation Tools.

[Project number and title (columns 1 and 2) include all projects highlighted in this report for each of the three research categories (1-3). The species focus (column 3) for each research project is identified as white-tailed deer (W), mule deer (M), elk (E), bighorn sheep (B), plants (P), voles (V), or not applicable (NA). Additional abbreviations: CWD, chronic wasting disease; PMCA, protein misfolding cyclic amplification; USGS, U.S. Geological Survey]

\begin{tabular}{|c|c|c|c|}
\hline $\begin{array}{l}\text { Research } \\
\text { project number } \\
\text { in this report }\end{array}$ & Research project title & $\begin{array}{l}\text { Species } \\
\text { focus }\end{array}$ & $\begin{array}{l}\text { Research conducted at USGS } \\
\text { Science Center or Cooperative } \\
\text { Research Unit (CRU) }\end{array}$ \\
\hline 1 & $\begin{array}{l}\text { Has CWD Produced Genetic Selection in Wisconsin White-Tailed Deer } \\
\text { Populations? }\end{array}$ & W & Wisconsin CRU \\
\hline 2 & CWD Shedding Across Cervid Species and Environmental Reservoirs & W, M, E & $\begin{array}{l}\text { Wisconsin CRU, National } \\
\text { Wildlife Health Center }\end{array}$ \\
\hline 4 & $\begin{array}{l}\text { Increasing Prevalence of CWD and Implications for Elk Population } \\
\text { Management at Wind Cave National Park, South Dakota }\end{array}$ & $\mathrm{E}$ & $\begin{array}{l}\text { Northern Prairie Wildlife } \\
\text { Research Center }\end{array}$ \\
\hline 5 & $\begin{array}{l}\text { Investigating the Genetic Diversity of the Prion Protein Gene Among } \\
\text { Subspecies of Bighorn Sheep }\end{array}$ & $\mathrm{B}$ & National Wildlife Health Center \\
\hline 6 & $\begin{array}{l}\text { Application of Landscape Genetic Techniques to Investigation of CWD } \\
\text { Dynamics and Transmission in Wisconsin White-Tailed Deer Populations }\end{array}$ & W & Wisconsin CRU \\
\hline 9 & $\begin{array}{l}\text { Developing a Targeted Mule Deer Chronic Wasting Disease Surveillance } \\
\text { Program in Montana }\end{array}$ & M & National Wildlife Health Center \\
\hline 10 & $\begin{array}{l}\text { When Good Habitats Go Bad: Modeling the Potential for Disease-Induced } \\
\text { Ecological Traps }\end{array}$ & NA & $\begin{array}{l}\text { Northern Rocky Mountain } \\
\text { Science Center }\end{array}$ \\
\hline 11 & Genetic Estimates of Mule Deer Connectivity in Montana & M & $\begin{array}{l}\text { Northern Rocky Mountain } \\
\text { Science Center }\end{array}$ \\
\hline 12 & $\begin{array}{l}\text { Elk Connectivity and Current and Potential Disease Movement Across the } \\
\text { Greater Yellowstone Ecosystem }\end{array}$ & $\mathrm{E}$ & $\begin{array}{l}\text { Northern Rocky Mountain } \\
\text { Science Center }\end{array}$ \\
\hline 13 & $\begin{array}{l}\text { Developing and Evaluating Spatial Analytical Techniques for Predictive } \\
\text { Modeling of Emerging Diseases of Epidemic Potential }\end{array}$ & M & $\begin{array}{l}\text { National Wildlife Health Center, } \\
\text { Colorado CRU }\end{array}$ \\
\hline
\end{tabular}


Table 1. List of U.S. Geological Survey research projects highlighted in this report that are organized by three research categories: (1) CWD Ecology and Epidemiology Studies, (2) CWD Risk Assessment and Modeling Studies, and (3) Development of CWD Surveillance and Mitigation Tools. - Continued

[Project number and title (columns 1 and 2) include all projects highlighted in this report for each of the three research categories (1-3). The species focus (column 3) for each research project is identified as white-tailed deer (W), mule deer (M), elk (E), bighorn sheep (B), plants (P), voles (V), or not applicable (NA). Additional abbreviations: CWD, chronic wasting disease; PMCA; protein misfolding cyclic amplification; USGS, U.S. Geological Survey]

\begin{tabular}{|c|c|c|c|}
\hline $\begin{array}{l}\text { Research } \\
\text { project number } \\
\text { in this report }\end{array}$ & Research project title & $\begin{array}{l}\text { Species } \\
\text { focus }\end{array}$ & $\begin{array}{l}\text { Research conducted at USGS } \\
\text { Science Center or Cooperative } \\
\text { Research Unit (CRU) }\end{array}$ \\
\hline 15 & $\begin{array}{l}\text { Risk Assessment of Captive Cervid Facilities in Pennsylvania: Implications to } \\
\text { the Spread of CWD }\end{array}$ & $\mathrm{W}$ & Pennsylvania CRU \\
\hline 16 & $\begin{array}{l}\text { Influence of Forested Habitats on Distribution of Chronic Wasting Disease in } \\
\text { White-Tailed Deer }\end{array}$ & W & Pennsylvania CRU \\
\hline 18 & $\begin{array}{l}\text { Factors Affecting CWD Transmission: A Comparison of CWD Epizootics in } \\
\text { Wisconsin and Illinois }\end{array}$ & $\mathrm{W}$ & Wisconsin CRU \\
\hline 19 & Modeling Effects of Environmental Persistence on Potential Deer Declines & $\mathrm{W}, \mathrm{M}, \mathrm{E}$ & $\begin{array}{l}\text { Northern Rocky Mountain } \\
\text { Science Center }\end{array}$ \\
\hline 23 & Degradation of Prions by a Serine Protease from Lichens & $\mathrm{P}$ & National Wildlife Health Center \\
\hline 24 & $\begin{array}{l}\text { Development of PMCA for Detection of CWD Prions in Environmental } \\
\text { Samples and Deer Tissues }\end{array}$ & W & Wisconsin CRU \\
\hline 25 & $\begin{array}{l}\text { Antemorten Detection of CWD Prions in Nasal Brush Collections and Rectal } \\
\text { Biopsy Specimens from White-Tailed Deer by Real-Time Quaking-Induced } \\
\text { Conversion }\end{array}$ & W & Pennsylvania CRU \\
\hline 26 & Improving Wildlife Disease Surveillance Using Epidemiological Knowledge & M & National Wildlife Health Center \\
\hline 27 & $\begin{array}{l}\text { Developing a Surveillance System for Early Detection of CWD for } \\
\text { Shenandoah National Park }\end{array}$ & $\mathrm{W}$ & $\begin{array}{l}\text { National Wildlife Health Center, } \\
\text { Virginia CRU }\end{array}$ \\
\hline
\end{tabular}




\section{Chronic Wasting Disease Ecology and Epidemiology Studies}

\section{Has Chronic Wasting Disease Produced Genetic Selection in Wisconsin White-Tailed Deer Populations?}

The prion protein gene (PRNP) encodes the protein associated with $\mathrm{CWD}\left(\mathrm{PrP}^{\mathrm{CWD}}\right)$ and other transmissible spongiform encephalopathies. PRNP genotypes in deer have differential resistance to CWD infection and show differential rates of disease progression. The most common genotype, the homozygous $96 \mathrm{GG}$, is over-represented among infected white-tailed deer. The less common 96GS genotype is associated with reduced susceptibility, reduced progression of CWD, or both. Despite theoretical and applied lessons from domestic and agricultural animals, there has been little investigation or evidence of genetic selection in the field of wildlife disease. Therefore, demonstrating selection would have significant implications for CWD management and on the epidemiology and future trends in CWD transmission and spread. A genetic assay was developed to genotype white-tailed deer at the 96th codon of PRNP (Robinson and others, 2012a). PRNP genetic variation was found with differential susceptibility of white-tailed deer to CWD. Deer with the more susceptible genotype (96GG) had over four-times greater risk of CWD infection, and deer with the resistant genotype (96GS) survived 49 percent longer (8.25 more months). A population matrix model was used to evaluate relative fitness based on genotype-specific population growth. The differences in disease infection and mortality rates allowed genetically resistant deer to achieve higher population growth and obtain a long-term fitness advantage (Robinson and others, 2012a). This suggests that the resistant allele could become dominant within an evolutionarily short time-frame. The work provides a rare example of a quantifiable disease-driven selection process in a wildlife population, demonstrating the potential for infectious diseases to alter host populations.

\section{Collaborator}

Wisconsin Department of Natural Resources

\section{Contact}

Michael D. Samuel (retired), Wisconsin Cooperative Wildlife Research Unit, mdsamuel@wisc.edu

\section{Publications}

Robinson, S., and Samuel, M.D., 2018, Are deer evolving resistance to CWD?: Quality Whitetails, April/May 2018, accessed at https://www.qdma.com/deer-evolving-resistance-cwd/.

Matsumoto, T., Samuel, M.D., Bolinger, T., Pybus, M., and Coltman, D.W., 2012, Association mapping of genetic risk factors for chronic wasting disease in wild deer: Evolutionary Applications, v. 6, no. 2, p. 340-352, accessed at https://doi.org/10.1111/eva.12003.

Robinson, S.J., Samuel, M.D., Johnson, C.J., Adams, M., and McKenzie, D.I., 2012a, Emerging prion disease drives host selection in a wildlife population: Ecological Applications, v. 22, no. 3, p. 1050-1059, accessed at http://www.jstor.org/stable/ pdf/23213937.pdf.

Robinson, S.J., Samuel, M.D., O'Rourke, K.I., and Johnson, C.J., 2012b, The role of genetics in chronic wasting disease of North American cervids: Prion, v. 6, no. 2, p. 153-162, accessed at https://doi.org/10.4161/pri.19640. 


\section{Chronic Wasting Disease Shedding Across Cervid Species and Environmental Reservoirs}

CWD management is hindered by the lack of key information about when and where animals shed CWD into the environment. Although environmental transmission is important in captive deer, no information exists on environmental reservoirs of CWD infection. Sensitive laboratory methods have recently been developed and refined (Protein misfolding cyclic amplification with beads [PMCAb]) that provide a practical solution for detecting CWD (Johnson and others, 2012). PMCAb was used to (1) determine the time of CWD shedding in urine and feces by white-tailed deer, mule deer, and elk; (2) compare shedding patterns among species, genotypes, and time; and (3) investigate mineral licks as reservoirs. $\operatorname{PrP}^{\mathrm{CWD}}$ was detected in 28 percent of cervid urine samples $(n=18)$, with no differences in shedding for species, genotype, or time post infection (PI). Compared to urine, detection in feces was 3-times higher ( 88 percent), but without differences in shedding for species or time PI. However, the results suggested that the PRNP genotype may be linked to shedding in feces, with more-susceptible genotypes being likely to shed CWD prions (94 percent) more than less-susceptible genotypes (64 percent). CWD was found at 9 of 11 mineral licks, suggesting these concentration areas could be effective reservoirs for transmitting disease. CWD was found in fecal samples collected in proximity to one of the mineral licks, confirming feces are a potential route of CWD deposition.

\section{Collaborators}

Wisconsin Department of Natural Resources

Joel Pedersen, Department of Soil Science, University of Wisconsin-Madison

USGS National Wildlife Health Center

Wyoming Department of Fish and Game

\section{Contact}

Michael D. Samuel (retired), Wisconsin Cooperative Wildlife Research Unit, mdsamuel@wisc.edu

\section{Publications}

Johnson, C.J., Aiken, J.M., McKenzie, D., Samuel, M.D., and Pedersen, J.A., 2012, Highly efficient amplification of chronic wasting disease agent by protein misfolding cyclic amplification with beads (PMCAb): PloS ONE, v. 7, no. 4, 7 p., accessed at https://doi.org/10.1371/journal.pone.0035383.

Plummer, I.H., Johnson, C.J., Chesney, A.R., Pedersen, J.A., and Samuel, M.D., 2018, Mineral licks as environmental reservoirs of chronic wasting disease prions: PLoS ONE. v. 13, no. 5, 13 p., accessed at https://doi.org/10.1371/journal.pone.0196745.

Plummer, I.H., Wright, S.D., Johnson, C.J., Pedersen, J.A., and Samuel, M.D., 2017, Patterns of chronic wasting disease prion excretion in three cervid species: Journal of General Virology, v. 98, p. 1932-1942, accessed at https://doi.org/10.1099/ jgv.0.000845.

\section{The Role of Environmental and Direct Transmission in Chronic Wasting Disease Dynamics}

The National Science Foundation funded a portion of a large-scale proposal to adapt, validate, and apply a novel, biochemical method to detect the pathogenic prions associated with CWD (PrP ${ }^{\mathrm{CWD}}$ ) (Johnson and others, 2012; Plummer and others, 2017; Plummer and others, 2018). When an animal is infected with a TSE, its normal prion protein $\left(\operatorname{PrP}^{\mathrm{C}}\right)$ is converted to a misfolded pathogenic protein ( $\left.\mathrm{PrP}^{\mathrm{TSE}}\right)$, which accumulates in the brain. For CWD, this misfolded protein is denoted as $\operatorname{PrP}^{\mathrm{CWD}}$. The goal of this project is to detect $\mathrm{PrP}^{\mathrm{CWD}}$ using the protein misfolding cyclical amplification (PMCA) method, which exploits the ability of $\mathrm{PrP}^{\mathrm{TSE}}$ to seed the conversion of the normal $\mathrm{PrP}^{\mathrm{C}}$ to the misfolded isoform in a manner conceptually similar to the polymerase chain reaction (PCR). PMCA, with the addition of Teflon beads (PMCAb) with saponin, dramatically increased the sensitivity of detection for CWD without compromising the specificity of the assay (Johnson and others, 2012). This increased the robustness of the PMCA reaction, resulting in a decrease in the variability of results. Three rounds of serial PMCAb allowed detection of the CWD agent from a $6.76 \times 10^{-13}$ dilution of 10 percent brain homogenate (1.3 femtograms [fg] of source brain). $\mathrm{PMCAb}$ is more sensitive than bioassay in transgenic mice by a factor exceeding $10^{5}$. Additionally, the CWD agent was amplified from brain tissue and lymph nodes of CWD-positive white-tailed deer. 


\section{Collaborator}

Joel Pedersen, Department of Soil Science, University of Wisconsin-Madison

\section{Contact}

Michael D. Samuel (retired), Wisconsin Cooperative Wildlife Research Unit, mdsamuel@wisc.edu

\section{Publication}

Johnson, C.J., Aiken, J.M., McKenzie, D., Samuel, M.D., and Pedersen, J.A., 2012, Highly efficient amplification of chronic wasting disease agent by protein misfolding cyclic amplification with beads (PMCAb): PLoS ONE, v. 7, no. 4, 7 p. [Also available at https://doi.org/10.1371/journal.pone.0035383.]

\section{Increasing Prevalence of Chronic Wasting Disease and Implications for Elk Population Management at Wind Cave National Park, South Dakota}

CWD was first observed in South Dakota in 1997 in a free-ranging white-tailed deer and in captive elk on property adjoining Wind Cave National Park $\left(43^{\circ} 35^{\prime} \mathrm{N}, 103^{\circ} 30^{\prime} \mathrm{W}\right)$. Thereafter, CWD quickly became the leading cause of death for adult female elk at the park, accounting for approximately one-third of annual mortality (13.2 percent total mortality) during 2005 to 2009 and two-thirds of annual mortality ( 18.7 percent total mortality) during 2011 to 2014 . This increase in mortality from CWD, to approximately 12.5 percent annually, coincided with, and reversed effects of, an unsuccessful attempt to regulate movements of elk across park boundaries and increase mortality from hunting outside of the park. Although effects of hunting were inadvertently reduced and elk numbers still exceeded objectives, mortality from CWD continued increasing to approximately 18 percent and substantially exceeded recruitment by 2017. Because high elk densities at Wind Cave National Park are not sustainable but exacerbate environmental contamination and risk of promoting the spread of CWD outside the park, the National Park Service culled 262 elk to reduce population density by about half during the winter of 2016-17. Future prospects of the herd are uncertain because effects of density on mortality of elk from CWD are not well understood. Moreover, results from neighboring Custer State Park $\left(43.7586^{\circ} \mathrm{N}, 103.4379^{\circ} \mathrm{W}\right)$ implicate cougar predation as the likely cause of low recruitment at Wind Cave National Park and suggest the effect is inversely density-dependent. As a result, Wind Cave National Park presents a unique and fortuitous opportunity to evaluate interacting effects of CWD, predation, and resource limitation on dynamics of wild elk.

\section{Collaborator}

National Park Service, Wind Cave National Park

\section{Contact}

Glen Sargeant, Northern Prairie Wildlife Research Center, gsargeant@usgs.gov

\section{Publication}

Sargeant, G.A., Weber, D.C., and Roddy, D.E., 2011, Implications of chronic wasting disease, cougar predation, and reduced recruitment for elk management: Journal of Wildlife Management v. 75, no. 1, p. 171-177, accessed at https://doi.org/10.1002/jwmg.27. 


\section{Investigating the Genetic Diversity of the Prion Protein Gene Among Subspecies of Bighorn Sheep}

The range of bighorn sheep overlaps many of the areas where CWD is endemic in free-ranging deer, as well as areas where scrapie in domestic sheep has been observed (fig. 3). Given the potential contact that bighorn sheep have with transmissible spongiform encephalopathies (TSEs), risk assessments of the susceptibility of bighorn sheep to both CWD and scrapie are warranted. Determining the sequence of the prion protein gene (PRNP) is one method to assess the potential susceptibility of a host to TSEs. USGS National Wildlife Heath Center scientists showed a small number of Rocky Mountain bighorn sheep from two herds in Washington State all possessed a genotype identical to a scrapie-susceptible domestic sheep $\left(\mathrm{A}^{136} \mathrm{R}^{154} \mathrm{Q}^{171}\right)$ (Morawski and others, 2013). Can scrapie cross the species barrier between domestic sheep (Ovis aries) and bighorn sheep (Ovis canadensis)? Using an in vitro prion protein conversion assay, scientists determined that the species barrier between bighorn sheep and domestic sheep scrapie was low, indicating risk of scrapie infection in bighorn sheep. Similarly, the species barrier for CWD between elk or white-tailed deer and bighorn sheep was low (Morawski and others, 2013). Bighorn sheep could be susceptible to CWD. Limitations of this 2013 study were (1) the small number of bighorn sheep sampled, (2) their origin from only two herds, and (3) testing only one subspecies of bighorn sheep. The purpose of this new study is to characterize the diversity of PRNP among various subspecies of bighorn sheep, including the endangered Sierra Nevada bighorn sheep, to assess the risk that TSEs could pose to these populations.

\section{Collaborators}

Nevada Department of Wildlife

Colorado Parks and Wildlife

California Department of Fish and Wildlife

\section{Contact}

Daniel P. Walsh, National Wildlife Health Center,dwalsh@usgs.gov

\section{Publication}

Morawski, A.R., Carlson, C.M., Chang, H., and Johnson, C.J., 2013, In vitro prion protein conversion suggests risk of bighorn sheep (Ovis canadensis) to transmissible spongiform encephalopathies: BMC Veterinary Research, v. 9, no. 1, p. 157, accessed at https://doi.org/10.1186/1746-6148-9-157. 


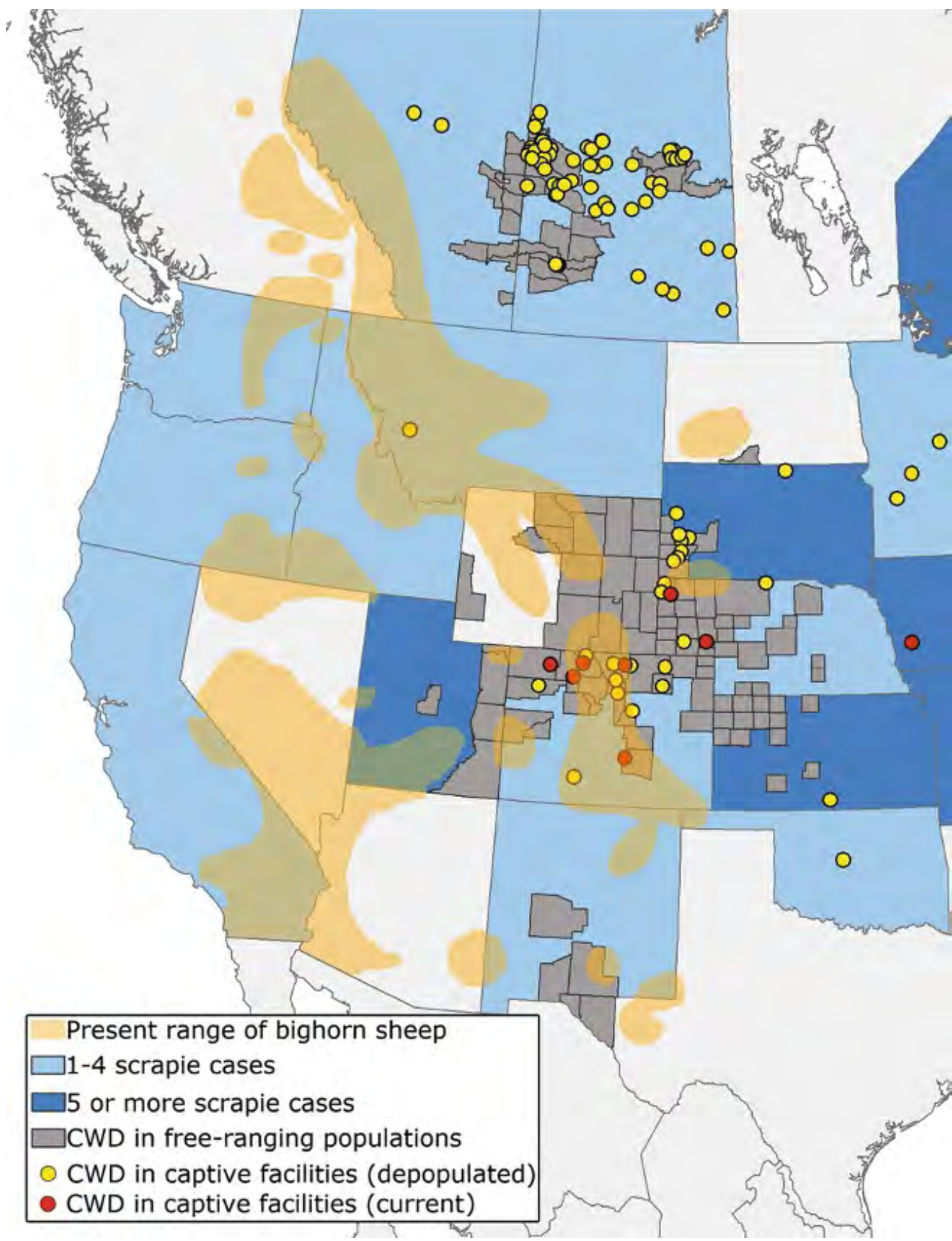

Figure 3. Western half of the United States and Canada showing the range of bighorn sheep in 2013 overlaps the occurrence of domestic sheep scrapie and chronic wasting disease (CWD). Number of cases of domestic sheep scrapie (light- and dark-blue) in a State or Canadian Province since 2008. Note that the "present" range of bighorn sheep is defined as "since 2008" (Morawski and others, 2013; p. 7). Also, the term "current" used for "CWD in captive facilities" is not defined in Morawski and others (2013). Abbreviation: CWD, chronic wasting disease. Unmodified figure from Morawski and others (2013) and licensed under the "Creative Commons Attribution 4.0 International (CC-BY 4.0)" public license (https://creativecommons.org/licenses/by/4.0/legalcode). 


\section{Application of Landscape Genetic Techniques to Investigation of Chronic Wasting Disease Dynamics and Transmission in Wisconsin White-Tailed Deer Populations}

CWD is a primary management concern related to Wisconsin's white-tailed deer population. Accurately characterizing the risks of transmission and spread from current outbreaks is crucial to achieving these goals. Because animal movements and gene flow are affected by landscape features, a landscape genetic analysis was performed to describe the population structure of white-tailed deer relative to core CWD outbreak locations (Robinson and others, 2013). Multidimensional scaling was employed to explore data patterns, followed by an analysis of similarity to test the hypothesis that ecological regions played a role in shaping population connectivity. A fine-scale social structure was described within different ecoregions using genetic correlograms and compared to correlograms showing fine-scale spatial patterns in CWD prevalence. Variations in white-tailed deer population structure were found that related to patterns of CWD prevalence, indicating that both may be subject to similar environmental drivers. Around the western Wisconsin CWD outbreak area, gene flow was more localized, suggesting that disease might be spread in short-distance steps from the western CWD core. Higher levels of gene flow around the eastern CWD outbreak indicated farther-ranging movement and more intermixing between deer social groups in this area, potentially leading to longer-distance spread of CWD.

\section{Collaborators}

Wisconsin Department of Natural Resources

Illinois Department of Natural Resources

\section{Contact}

Michael D. Samuel (retired), Wisconsin Cooperative Wildlife Research Unit, mdsamuel@wisc.edu

\section{Publication}

Robinson, S.J., Samuel, M.D., Rolley, R., and Shelton, P., 2013, Using landscape epidemiological models to understand factors affecting the distribution of chronic wasting disease in the Midwestern USA: Journal of Landscape Ecology, v. 28, no. 10, p. 1923-1935, accessed at http://link.springer.com/article/10.1007/s10980-013-9919-4.

\section{An R Package for Prion Sequence Analysis in Cervids}

Genetic variation within the prion gene of many cervids has been linked to reductions in perceived susceptibility to chronic wasting disease (CWD). Previous research suggests that certain nonsynonymous polymorphisms can lead to differences in genotype-specific infection and prevalence rates (Robinson and others, 2012b). Understanding the frequency and distribution of prion genotypes may provide insights into future epidemiology and infection intensity, particularly in areas of recent infection. The objective of this study was to create a package, implemented in program R, to provide a unified framework for analyzing prion protein gene variability and spatial structure in cervid species. Prion sequences were collected from a subset of elk and analyzed using a newly created analytical package, CWDPRNP (Miller and Walter 2017). This package provides a user-friendly interface for researchers to assess prion genotypes for various cervid species using commonly used primers. CWDPRNP requires (1) a reference sequence into the $\mathrm{R}$ environment from GenBank for a particular cervid species or accession number, (2) results from Applied Biosystems platforms (that is ab1), and (3) shapefiles of landscapes that study species occupied at the time of tissue sample collection. Spatial interpolation can be incorporated into the package using the shapefiles to compare genotype frequencies among subpopulations of each species across a landscape of study. This package provides a variety of tools for (1) identifying PRNP sequence variation among individuals via multiple sequence alignment, (2) determining population-level genotype and allele frequencies of PRNP gene variants, and (3) visualizing spatial genetic structure of disease-associated alleles and genotypes that was previously unavailable.

\section{Collaborator}

Pennsylvania Game Commission 


\section{Contact}

W. David Walter, Pennsylvania Cooperative Fish and Wildlife Research Unit,wdw12@psu.edu

\section{Publication}

Miller, W.L., and W.D., Walter, 2017, CWDPRNP_A tool for cervid prion sequence analysis in program R: Bioinformatics, v. 33, no. 19, p. 3096-3097, accessed at https://doi.org/10.1093/bioinformatics/btx333.

\section{Chronic Wasting Disease Risk Assessment and Modeling Studies}

\section{Spatial Modeling of Chronic Wasting Disease Epizootiology and Disease Management Strategies}

Few studies have evaluated the rate of infection or mode of transmission for wildlife diseases, and the implications of alternative management strategies. Wisconsin hunter harvest data were used to investigate CWD infection rate and transmission modes, and address how alternative management approaches affect disease dynamics (Jennelle and others, 2014). Uncertainty regarding demographic impacts of CWD on cervid populations, human and domestic animal health concerns, and potential economic consequences underscore the need for strategies to control CWD. Maximum-likelihood methods were used to evaluate alternative models of CWD transmission. Data strongly supported a frequency-dependent transmission structure with sex-specific infection rates that are two times higher in males than in females. This means that harvest targeting on males can result in stable population dynamics and possible control of CWD within the next 50 years. A quantitative estimate of geographic disease spread in southern Wisconsin was provided, validating qualitative assessments that CWD spreads relatively slowly. Given increased discovery and distribution of CWD throughout North America, insights from the study are valuable to management agencies and to the general public that are concerned about the impacts of CWD on white-tailed deer populations.

\section{Collaborator}

Wisconsin Department of Natural Resources

\section{Contact}

Michael D. Samuel (retired), Wisconsin Cooperative Wildlife Research Unit, mdsamuel@wisc.edu

\section{Publication}

Jennelle, C.S., Henaux, V., Wasserberg, G., Thiagarajan, B., Rolley, R.E., and Samuel, M.D., 2014, Transmission of chronic wasting disease in Wisconsin white-tailed deer-Implications for disease spread and management: PLoS ONE, v. 9, no. 3, 12 p., accessed at https://doi.org/10.1371/journal.pone.0091043.

\section{Developing a Targeted Mule Deer Chronic Wasting Disease Surveillance Program in Montana}

In 2015, the office of Montana Fish, Wildlife and Parks was interested in developing a targeted cost-effective surveillance program for CWD. Though no cases of CWD had been documented in the State of Montana at that time, cases of CWD had been found less than 50 miles away in Saskatchewan, Canada, and Wyoming. Areas of "high risk" for CWD introduction were identified by overlapping maps of mule deer density and estimating the distance to the nearest infected herd (Russell and others, 2015). For this project, mule deer density across the State of Montana was estimated using (1) aerial survey data to estimate deer numbers, and (2) resource-selection functions to distribute the deer across a habitat-suitability gradient. Maps of estimated deer density and estimated distance to the nearest known infected herd were overlapped to identify areas where deer densities were predicted to be high and distances to infected herds were minimal. Areas in north-central and southeastern Montana were 
identified as high risk, and CWD was discovered there in 2017. The information continues to be used by the State of Montana to design targeted surveillance programs for CWD in mule deer.

\section{Collaborator}

Montana Fish, Wildlife and Parks

\section{Contact}

Robin Russell, USGS National Wildlife Health Center, rerussell@usgs.gov

\section{Publication}

Russell, R.E., Gude, J.A., Anderson, N.J., and Ramsey, J.M., 2015, Identifying priority chronic wasting disease surveillance areas for mule deer in Montana: Journal of Wildlife Management; v. 79, no. 6, p. 989-997, accessed at http://onlinelibrary.wiley.com/doi/10.1002/jwmg.914/epdf.

\section{When Good Habitats Go Bad: Modeling the Potential for Disease-Induced Ecological Traps}

Prions associated with CWD can persist in the environment for years. Simulation modeling suggests that this environmental persistence may drive the spread of CWD and associated population declines (Almberg and others, 2011). The benefits of high-quality habitats may be modulated by the presence of environmentally persistent pathogens like CWD. In some cases, the pathogen may lead to the creation of ecological traps, wherein hosts preferentially colonize habitat that is perceived as good but are then exposed to increased disease-induced mortality. A metapopulation modeling approach was used in this study to describe the parameter space where ecological traps are likely to occur (Leach and others, 2016).

\section{Collaborator}

Colorado State University

\section{Contact}

Paul Cross, Northern Rocky Mountain Science Center, pcross@usgs.gov

\section{Publications}

Almberg, E.S., Cross, P.C., Johnson, C.J., Heisey, D.M., and Richards, B.J., 2011, Modeling routes of chronic wasting disease transmission-Environmental prion persistence promotes deer population decline and extinction, PloS ONE, v. 6, no. 5, 11 p., accessed at https://doi.org/10.1371/journal.pone.0019896.

Leach, C.B., Webb, C.T., and Cross, P.C., 2016. When environmentally persistent pathogens transform good habitat into ecological traps: Open Science, v. 3, no. 3, 11 p., accessed at https://doi.org/10.1098/rsos.160051.

\section{Genetic Estimates of Mule Deer Connectivity in Montana}

CWD has been detected in mule deer in South Dakota, Wyoming, and Canadian provinces bordering Montana (U.S. Geological Survey, 2016). In order to understand the potential spread of CWD through mule deer populations in this region, multiple genetic approaches (microsatellites to endogenous retroviruses) were utilized to estimate connectivity of mule deer populations. All of these genetic approaches suggested high levels of mule deer connectivity across the region (Powell and others, 2013; Kamath and others, 2014). This connectivity is consistent with radiotelemetry studies that document long-distance movements of mule deer (Sawyer and others, 2014). In terms of population connectivity, there are minimal barriers to future CWD spread in this region (Powell and others, 2013; Kamath and others, 2014). 


\section{Collaborator}

Montana Fish, Wildlife and Parks

\section{Contact}

Paul Cross, Northern Rocky Mountain Science Center,pcross@usgs.gov

\section{Publications}

Kamath, P.L., Elleder, D., Bao, L., Cross, P.C., Powell, J.H., and Poss, M., 2014, The population history of endogenous retroviruses in mule deer (Odocoileus hemionus): Journal of Heredity, v. 105, no. 2, p. 173-187, accessed at https://doi.org/10.1093/jhered/est088.

Powell, J.H., Kalinowski, S.T., Higgs, M.D., Ebinger, M.R., Vu, N.V., and Cross, P.C., 2013, Microsatellites indicate minimal barriers to mule deer Odocoileus hemionus dispersal across Montana, USA: Wildlife Biology, v. 19, no. 1, p. 102-110, accessed at https://doi.org/10.2981/11-081.

\section{Elk Connectivity and Current and Potential Disease Movement Across the Greater Yellowstone Ecosystem}

Elk are the most abundant large mammal in the Greater Yellowstone Ecosystem (GYE) besides cattle (National Academies of Sciences, Engineering, and Medicine, 2017) and are at risk for CWD. Spatial spread of an invasive species or pathogen is often driven by rare long-distance dispersals (LDDs), rather than mean movement and diffusion (Hastings and others, 2005). Thus, it is critical to characterize the tail of a dispersal distribution, which tends to be difficult in wildlife systems where sampling is limited. In addition, dispersal analyses may be conducted without regard for potential effects of landscape heterogeneity on extreme long-distance movements. For this project, working with State and Federal collaborators, over 12 million global-positioning-system fixes were compiled on over 1,400 elk in the GYE, providing an opportunity to study the effects of landscape on the rare dispersal events that drive spatial disease spread. This information will be compared to genomewide DNA markers from more than 2,400 elk to assess elk connectivity across the region. Regional elk connectivity data will provide insight into the risk for future CWD spread.

\section{Collaborators}

Montana Fish, Wildlife and Parks

Wyoming Game and Fish Department

Idaho Fish and Game Department

U.S. Fish and Wildlife Service

Yellowstone National Park, National Park Service

University of Montana

\section{Contact}

Paul Cross, Northern Rocky Mountain Science Center,pcross@usgs.gov

\section{Publications}

Brennan, A., Hanks, E.M., Merkle, J.A., Cole, E.K., Dewey, S.R., Courtemanch, A.B., and Cross, P.C., 2018, Examining speed versus selection in connectivity models using elk migration as an example: Landscape Ecology, v. 33, no. 6, p. 955-968, accessed at https://doi.org/10.1007/s10980-018-0642-z. 
Hand, B.K., Chen, S., Anderson, N., Beja-Pereira, A., Cross, P.C., Ebinger, M., Edwards, W.H., Garrott, R.A., Kardos, M., Kauffman, M., Middleton, A., Schwartz, M., White, P.J., Zager, P., Landguth, E.L., and Luikart, G., 2014, Sex-biased gene flow among elk in the greater Yellowstone ecosystem: Journal of Fish and Wildlife Management, v. 5, no. 1, p. 124-132, accessed at https://doi.org/10.3996/022012-JFWM-017.

Wijeyakulasuriya, D.A., Hank, E.M., Shaby, B.A., and Cross, P.C., 2019, Extreme value-based methods for modeling elk yearly movements: Journal of Agricultural, Biological and Environmental Statistics, v. 24, no. 1, p. 73-91, accessed at https://doi.org/10.1007/s13253-018-00342-2.

\section{Developing and Evaluating Spatial Analytical Techniques for Predictive Modeling of Emerging Diseases of Epidemic Potential}

The USGS and others are actively evaluating and developing tools for the efficient and valid analysis of spatial-temporal data that reduces the impacts on inference of the statistical phenomena of spatial confounding, which plagues most currently available statistical methods for these types of data. A novel group-lasso technique was developed by the USGS and collaborators that can be useful for regularizing spatial models when multicollinearity between spatially indexed and structured covariates and random effects occurs (spatial confounding). This method has both desirable statistical and computation properties. Additionally, the use of partial differential equation models was explored, under the constraints of "big data," to alleviate the issues of multicollinearity and provided a mechanistic framework to investigate and forecast disease growth within a population and its spread through a region. The implementation of this ecological diffusion model (Hefley and others 2017a, c) and the group-lasso methodology (Hefley and others, 2017b) was demonstrated using a long-term, spatial-temporal dataset of CWD from Wisconsin.

\section{Collaborators}

Kansas State University

Wisconsin Department of Natural Resources

\section{Contacts}

Daniel P. Walsh, USGS National Wildlife Health Center, dwalsh@usgs.gov

Mevin B. Hooten, USGS Colorado Cooperative Fish and Wildlife Research Unit, mhooten@usgs.gov

Robin E. Russell, USGS National Wildlife Health Center, rerussell@usgs.gov

\section{Publications}

Hefley, T.J., Hooten, M.B., Drake, J.M., Russell, R.E., and Walsh, D.P., 2016, When can the cause of population decline be determined?: Ecology Letters, v. 19, no. 11, p. 1353-1362, accessed at https://doi.org/10.1111/ele.12671.

Hefley, T.J., Hooten, M.B., Hanks, E.M., Russell, R.E., and Walsh, D.P., 2017a, Dynamic spatio-temporal models for spatial data: Spatial Statistics, v. 20, p. 206-220, accessed at https://doi.org/10.1016/j.spasta.2017.02.005.

Hefley, T.J., Hooten, M.B., Hanks, E.M., Russell, R.E., and Walsh, D.P., 2017b, The Bayesian group lasso for confounded spatial data: Journal of Agricultural, Biological, and Environmental Statistics, v. 22, no. 1, p. 42-59, accessed at https://link.springer.com/article/10.1007/s13253-016-0274-1.

Hefley, T.J., Hooten, M.B., Russell R.E., Walsh, D.P., and Powell J.A., 2017c, When mechanism matters-Bayesian forecasting using models of ecological diffusion: Ecology Letters, v. 20, p. 640-650, accessed at https://doi.org/10.1111/ele.12763. 


\section{Linking Process to Pattern: Estimating Chronic Wasting Disease Dynamics in Space and Time}

Using five years of hunter-harvest prevalence data from Wisconsin's CWD epidemic in white-tailed deer, a Bayesian approach was developed and explored that allowed for a detailed examination of factors modulating the infection rates over space, age, and time (Heisey and others, 2010). The Bayesian ability to "borrow strength" from neighbors in both space and time allows for model flexibility, yet provides enough structure for well-behaved estimation. Synthesizing a number of areas of event time analysis (current status data, age/period/cohort models and (or) Bayesian spatial shared frailty models), the general framework has very broad ecological applicability beyond disease prevalence data to a number of important ecological event time analyses, including general survival studies, for which current methods are ill-suited, especially when multiple time scales are of interest.

\section{Contact}

Paul Cross, Northern Rocky Mountain Science Center, pcross@usgs.gov

\section{Publications}

Heisey, D.M., Osnas, E.E., Cross, P.C., Joly, D.O., Langenberg, J.A., and Miller, M.W., 2010, Linking process to patternEstimating spatiotemporal dynamics of a wildlife epidemic from cross-sectional data: Ecological Monographs, v. 80, no. 2, p. 221-240, accessed at https://doi.org/10.1890/09-0052.1.

Heisey, D.M., Osnas, E.E., Cross, P.C., Joly, D.O., Langenberg, J.A., and Miller, M.W., 2010, Rejoinder—Shifting through model space: Ecology, v. 91, no. 12, p. 3503-3514, accessed at https://doi.org/10.1890/10-0894.1.

\section{Risk Assessment of Captive Cervid Facilities in Pennsylvania: Implications to the Spread of Chronic Wasting Disease}

Captive cervid facilities are common throughout the United States, and in particular Pennsylvania (841 captive cervid facilities; Carrollo, 2016), which is second only to Texas in the number of captive cervid facilities within the State with over 1,000. These facilities can pose a large risk to wild deer populations because of disease transmission issues, and in particular, they pose a serious threat via the spread of CWD. Regulations exist to prevent disease spread, but are minimal and often hard to enforce. The location characteristics of captive cervid facility owners in Pennsylvania were identified using environmental and facility variables (Carrollo, 2016). These variables were used to create a predictive surface of areas with a greater risk of potential CWD transmission between captive and wild deer populations. Multiple geographic-information-system layers were collected that included elevation, land cover, Pennsylvania county and parcel information, and Pennsylvania public lands (State parks, National parks, game lands, etc.). Information from 841 captive facilities also was collected to create stocking density and deer movement variables. Negative binomial regression was used to assess 13 a priori models because of the distribution issues typically encountered with count data. Results indicated that agriculture occurred around captive facilities with positive coefficients and confidence intervals that did not overlap zero. High wild deer density, average stocking density, and elevation also had varying effects on selection of location for a cervid facility by owners. A predictive surface was created to identify areas with the potential for the most risk of CWD transmission between wild and captive deer that can be used by wildlife managers to assess where CWD testing will be most effective.

\section{Collaborators}

Pennsylvania Department of Agriculture

The Pennsylvania State University

\section{Contact}

W. David Walter, Pennsylvania Cooperative Fish and Wildlife Research Unit,wdw12@psu.edu 


\section{Publication}

Carrollo, E.M., 2016, Exploration of methods for analyses of resource selection using location-based data: University Park, Penn., Pennsylvania State University, M.S. thesis, 62 p., accessed at https://etda.libraries.psu.edu/catalog/28912.

\section{Influence of Forested Habitats on Distribution of Chronic Wasting Disease in White- Tailed Deer}

Because CWD is a new and emerging disease with a spatial distribution that had yet to be assessed in the northeastern United States (Evans and others, 2014), fixed (demographic and environmental) and random effects were examined to determine how each related to the spatial distribution (Evans and others, 2016). The objectives of the study were to (1) identify fixed and random effects that best described the spatial distribution of CWD in free-ranging white-tailed deer and (2) identify areas at risk for CWD infection in the northeastern United States. Demographic covariates included sex and age, and environmental covariates included elevation, slope, riparian corridor, percent clay, and proportion of 3 habitat types (developed, forested, and open). The model with the most support contained habitat covariates and random spatial effects that represented clustering of CWD in adjacent grid cells. Forested habitat had the strongest relationship with the distribution of CWD, with increased risk of CWD occurring in areas that had lesser amounts of forest (fig. 4). The results can assist resource managers in understanding the spatial distribution of CWD not only within the study area, but also in surrounding areas where CWD has yet to be found. Efficiency of disease surveillance and containment efforts can be improved by allocating resources used for surveillance into areas that are at greatest risk for infection.

\section{Collaborators}

Virginia Department of Game and Inland Fisheries

Maryland Department of Natural Resources

Pennsylvania Game Commission

\section{Contact}

W. David Walter, Pennsylvania Cooperative Fish and Wildlife Research Unit, wdw12@psu.edu

\section{Publications}

Evans, T.S., Kirchgessner, M.S., Eyler, B., Ryan, C.W., and Walter, W.D., 2016, Habitat influences distribution of chronic wasting disease in white-tailed deer: Journal of Wildlife Management, v. 80, no. 2, p. 284-291, accessed at https://doi.org/10.1002/jwmg.1004.

Evans, T.S., Schuler, K.L., and Walter, W.D., 2014, Surveillance and monitoring of white-tailed deer for chronic wasting disease in the northeastern United States: Journal of Fish and Wildlife Management, v. 5, no. 2, p. 387-393, accessed at https://doi.org/10.3996/032014-JFWM-021. 


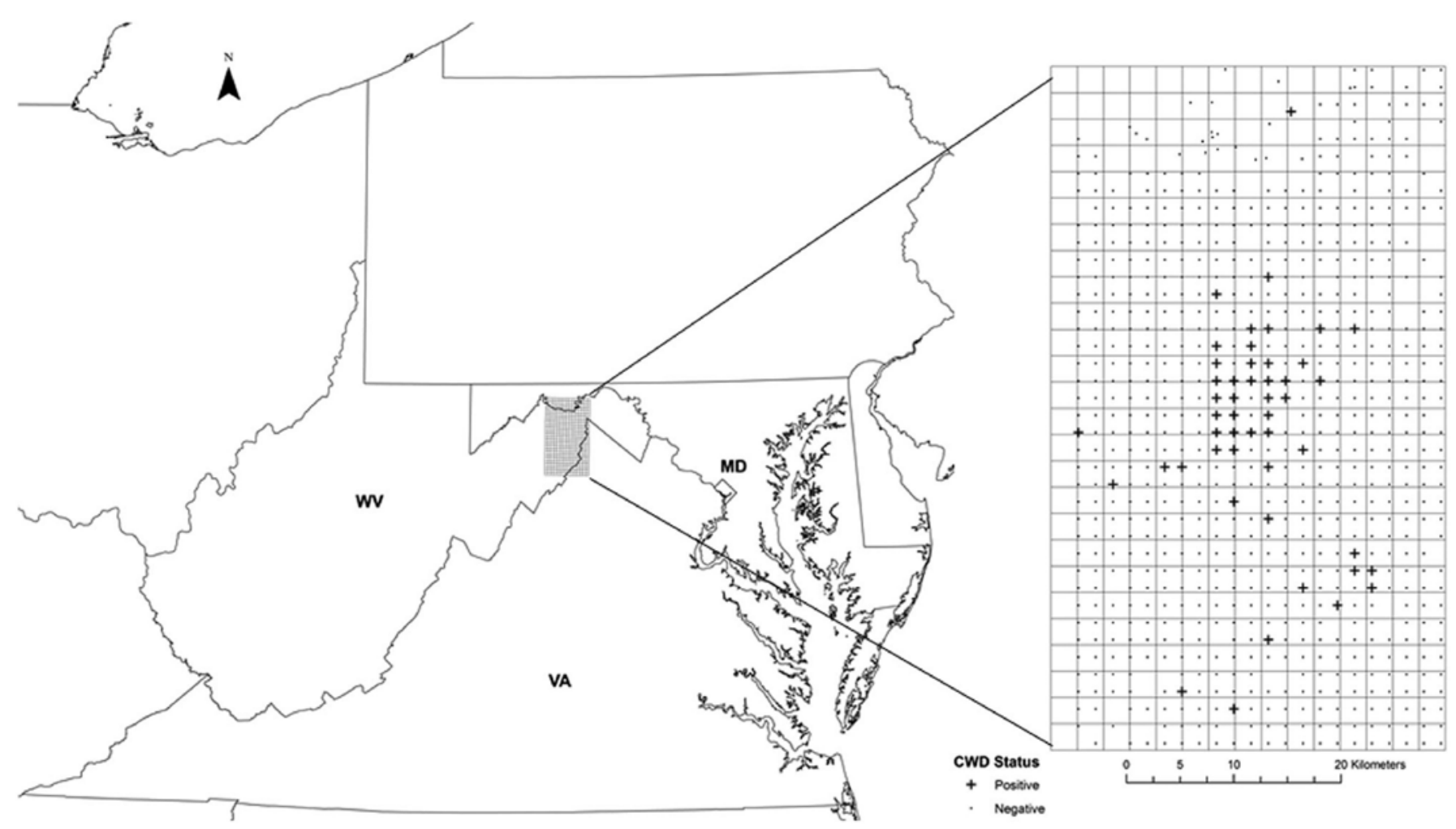

Figure 4. Study area in the central Appalachian region of the northeastern United States. The inset identifies the sampling grid and locations of all positive (+) and negative (.) samples used to model chronic wasting disease (CWD) in white-tailed deer between 2005 and 2012. Forested landscapes had the strongest relationship with the distribution of CWD, with increased risk of CWD occurring in areas that had lesser amounts of forest. Abbreviations: CWD, chronic wasting disease; MD, Maryland; VA, Virginia; WV, West Virginia. Figure from Evans and others (2016) and used with permission from John Wiley \& Sons, Inc., at https://onlinelibrary.wiley.com/journal/19372817.

\section{Factors Affecting the Risk of Chronic Wasting Disease Infection in Male White-Tailed Deer: Implications for Managing Chronic Wasting Disease in Wisconsin}

Potential management and control of CWD prevalence may be hindered by the lack of key information about risk factors and disease transmission to adult males. It was previously determined that risk factors for adult females and yearlings primarily relate to social group contact and disease prevalence (Grear and others, 2010; Jenelle and others, 2014). However, risk factors for adult males were unknown. Understanding the risk factors for adult males may provide keys to future management and control of CWD. A retrospective analysis was conducted of infection in adult males to identify potential factors associated with risk of CWD infection in males (Samuel and Storm, 2016). The results indicated that adult males were 3 times more likely to become infected than females. In Wisconsin, males had higher disease-related mortality than female deer, but this difference was not apparent in Illinois. Transmission of CWD among male deer during the nonbreeding season may be a reasonable mechanism for producing higher rates of infection and prevalence characteristically found in males. Alternatives based on high environmental transmission and transmission from females to males during the breeding season may also play an important role.

\section{Collaborators}

Wisconsin Department of Natural Resources Illinois Department of Natural Resources

\section{Contact}

Michael D. Samuel (retired), Wisconsin Cooperative Wildlife Research Unit, mdsamuel@wisc.edu 


\section{Publication}

Samuel, M.D., and Storm, D.J., 2016, Chronic wasting disease in white-tailed deer-Infection, mortality, and implications for heterogeneous transmission: Ecology, v. 97, no. 11, p. 3195-3205, accessed at https://doi.org/10.1002/ecy.1538.

\section{Factors Affecting Chronic Wasting Disease Transmission: A Comparison of Chronic Wasting Disease Epizootics in Wisconsin and Illinois}

Host culling is the primary tool used to manage many diseases, including CWD in white-tailed deer (Odocoileus virginianus), and can be effective when disease transmission rates are driven by density-dependent infectious contact between hosts, but not when transmission rates are density-independent (frequency-dependent) (Jenelle and others, 2014). The influence of deer density and landscape variables on transmission of CWD were evaluated in white-tailed deer in south-central Wisconsin and northeastern Illinois. The data consisted of CWD infection status, sex, age, and spatial location (2.59 square kilometer $\left[\mathrm{km}^{2}\right]$ grid), and deer-density estimates from helicopter surveys (Storm and others, 2013). Ages of harvested white-tailed deer are often estimated using tooth replacement and wear criteria, which is somewhat subjective and error-prone. Models were fitted that represented frequency-dependent, density-dependent, and non-linear density-dependent transmission hypotheses. Density-dependent models were better than the frequency-dependent model, suggesting that reducing deer populations, reducing density of infected deer, or both could aid in CWD management. In addition to replacement and wear, cementum annuli were used to determine the age of 1,261 adult (greater than or equal to 1.5 years old) white-tailed deer harvested in Wisconsin and Illinois. Cementum annuli were compared with wear-and-replacement estimates to assess misclassification rates in relation to sex and age and some consequences of misclassification. A two-sample correction method was applied to estimate the true age structure of the deer harvest. The corrected age structure is older than the estimated age by wear-and-replacement, and ageclass misclassification leads to biased estimates of age-specific prevalence of chronic wasting disease (Storm and others, 2015). Fixed-wing forward-looking infrared imaging (FLIR) and helicopter counts were compared to evaluate relative bias, influence of snow cover, and cost. Deer populations were surveyed on 5 plots using both fixed-wing FLIR and helicopters, both with snow cover and without snow. Neither method counted more deer than the other when snow was present. Helicopter counts were strongly influenced by the presence of snow, while variability was high with no consistent influence of snow using FLIR. FLIR counts were inconsistent between survey conditions (snow versus no snow), suggesting that detection rates vary over larger time scales (Storm and others, 2011). Further research is needed to understand what factors influence detection of deer during FLIR surveys.

\section{Collaborators}

Wisconsin Department of Natural Resources

Illinois Department of Natural Resources

USGS National Wildlife Health Center

\section{Contact}

Michael D. Samuel (retired), Wisconsin Cooperative Wildlife Research Unit, mdsamuel@wisc.edu

\section{Publications}

Storm, D.J., Samuel, M.D., Rolley, R.E., Beissel, T., Richards, B.J., and Van Deelen, T.R., 2015, Estimating ages of white-tailed deer-Age and sex patterns of error using tooth wear-and-replacement and consistency of cementum annuli: Wildlife Society Bulletin, v. 38, no. 4, p. 849-856, accessed at https://doi.org/10.1002/wsb.457.

Storm, D.J., Samuel, M.D., Rolley, R.E., Shelton, P., Keuler, N.S., Richards, B.J., and Van Deelen, T.R., 2013, Deer density and disease prevalence influence transmission of chronic wasting disease in white-tailed deer: Ecosphere, v. 4, no. 1, p. 1-14, accessed at https://doi.org/10.1890/ES12-00141.1.

Storm, D.J., Samuel, M.D., Van Deelen, T.R., Malcolm, K.D., Rolley, R.E., Frost, N.A., Bates, D.P., and Richards, B.J., 2011, Comparison of visual-based helicopter and fixed-wing forward-looking infrared surveys for counting white-tailed deer Odocoileus virginianus: Wildlife Biology, v. 17, no. 4, p. 431-440, accessed at https://doi.org/10.2981/10-062. 


\section{Modeling Effects of Environmental Persistence on Potential Deer Declines}

Simulation models were used to demonstrate how the duration of the environmental prion persistence may affect epidemics of CWD and deer populations (Almberg and others, 2011). Data from the literature were used to define plausible short-term outcomes and the associated parameter spaces. Despite relatively low epidemic growth rates, the basic reproductive number $\left(\mathrm{R}_{0}\right)$, which is an index of how invasive a pathogen is, may be much larger than expected because the infectious period can vastly exceed the host's life span (Miller and others, 2004; Georgsson and others, 2006). High prion persistence is expected to lead to an increasing environmental pool of prions (fig. 5). As a consequence, over this period of time, disease dynamics will become more heavily influenced by indirect transmission, which may explain some of the observed regional differences in age and sex-specific disease patterns.

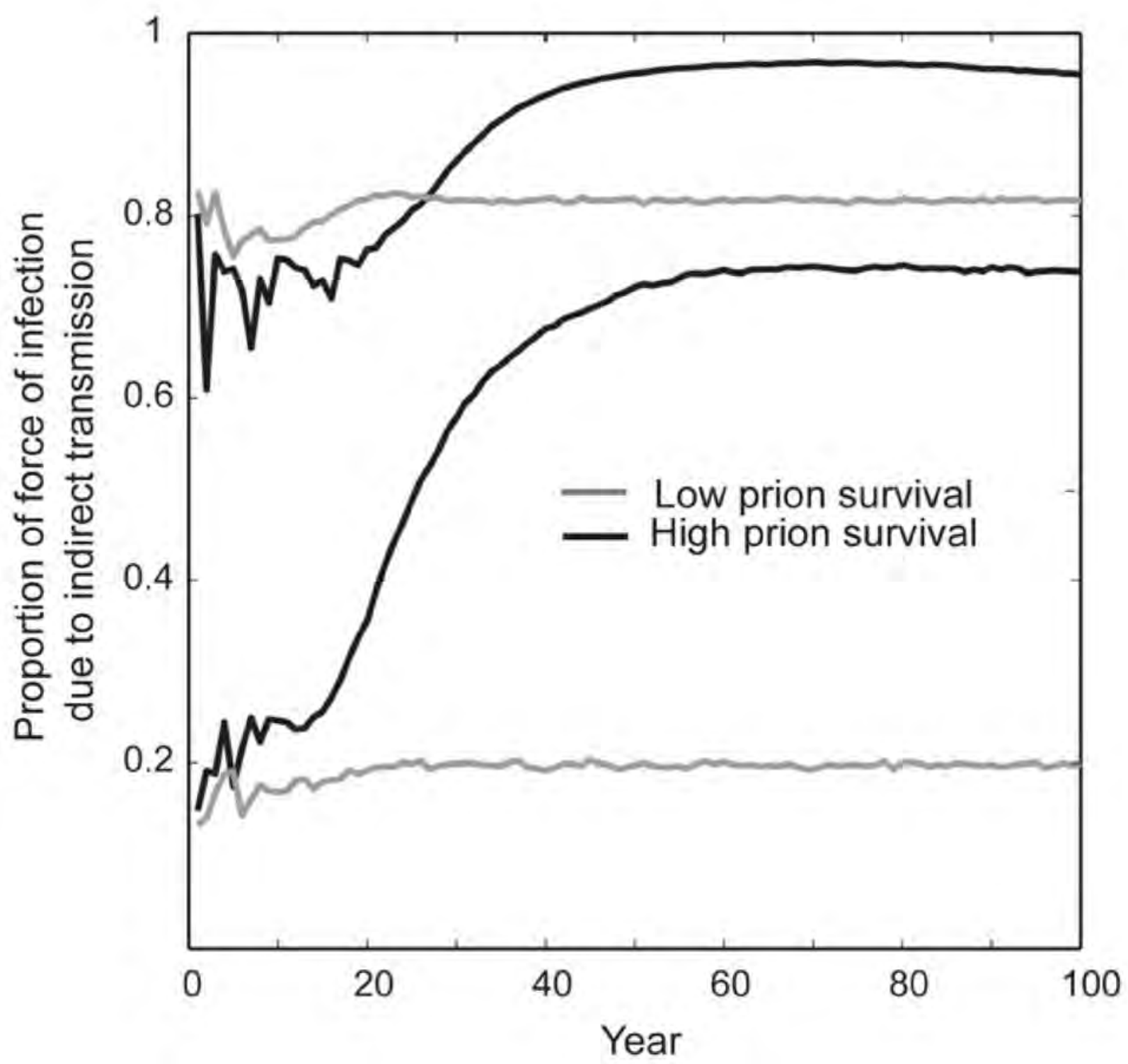

Figure 5. Proportion of the force of infection due to indirect transmission increases over time and varies with respect to prion survival. The gray lines represent typical dynamics when prion survival is low (0.25-year half-life), whereas the black lines represent typical dynamics when prion survival is high (8-year half-life). The two sets of lines reflect starting assumptions of high or low transmission from the environment. The $\mathrm{x}$-axis units given as "year" refers to the total number of years of the study and not to a calendar year. Unmodified figure from Almberg and others (2011) and licensed under the "Creative Commons Attribution 4.0 International (CC BY 4.0)" public license (https://creativecommons.org/licenses/by/4.0/legalcode). 


\section{Contact}

Paul Cross, USGS Northern Rocky Mountain Science Center, pcross@usgs.gov

\section{Publication}

Almberg, E.S., Cross, P.C., Heisey, D., Johnson, C.J., and Richards, B.J., 2011, Modeling routes of chronic wasting disease transmission-Environmental prion persistence promotes deer population decline and extinction: PLoS ONE, v. 6, no. 5, 11 p., accessed at https://doi.org/10.1371/journal.pone.0019896.

\section{Assessing the Risk of Prion Disease Transmission to Bighorn Sheep}

Transmissible spongiform encephalopathies (TSEs) affect both domestic sheep (for example, scrapie) and captive and free-ranging cervids (for example, CWD). The geographical range of bighorn sheep overlaps with U.S. States or Canadian provinces that have contained scrapie-positive sheep or goats and areas with present epizootics of CWD in cervids (fig. 3). No TSEs have been documented in bighorn sheep, but the susceptibility of this species to TSEs remains unknown. A library of bighorn sheep tissues was acquired and revealed no evidence of preexisting TSEs in these animals (Morawski and others, 2013). The prion protein gene (PRNP) in all bighorn sheep in the library was identical to scrapie-susceptible domestic sheep $\left(\mathrm{A}^{136} \mathrm{R}^{154} \mathrm{Q}^{171}\right.$ genotype). Using an in vitro prion protein conversion assay, which was previously used to assess TSE species barriers (Johnson and others, 2015) and, in this study appears to recollect known species barriers in mice, the potential transmissibility of TSEs to bighorn sheep was assessed. Based on PRNP genotype, bighorn sheep prion protein conversion by classical scrapie agent and evidence for a species barrier between transmissible mink encephalopathy (TME) and bighorn sheep were observed. Interestingly, the data suggest that the species barrier of bighorn sheep to white-tailed deer or wapiti CWD agents is likely low. Protein misfolding cyclic amplification also was used to confirm that CWD, but not TME, can template prion protein misfolding in $\mathrm{A}^{136} \mathrm{R}^{154} \mathrm{Q}^{171}$ genotype sheep. The results indicate the in vitro conversion assay used in the study mimics the species barrier of mice to the TSE agents that were tested. Based on PRNP genotype and results from conversion assays, bighorn sheep are likely to be susceptible to infection by classical scrapie. Despite mismatches in amino acids thought to modulate prion protein conversion, the data indicate that $\mathrm{A}^{136} \mathrm{R}^{154} \mathrm{Q}^{171}$ genotype sheep prion protein is misfolded by CWD agent, suggesting that these animals could be susceptible to CWD. Further investigation of TSE transmissibility to bighorn sheep, including animal studies, is warranted. The lack of reported TSEs in bighorn sheep may be attributable to other host factors or a lack of TSE surveillance in this species.

\section{Collaborator}

University of Wisconsin-Madison

\section{Contact}

Christopher Johnson, USGS Office of Science Quality and Integrity, cjjohnson@usgs.gov

\section{Publications}

Johnson, C.J., Carlson, C.M., Morawski, A.R., Manthei, A., and Cashman, N.R., 2015, Assessing transmissible spongiform encephalopathy species barriers with an in vitro prion protein conversion assay: Journal of Visualized Experiments, v. 97, p. e52522, accessed at https://doi.org/10.3791/52522.

Morawski, A.R., Carlson, C.M., Chang, H., and Johnson, C.J., 2013, In vitro prion protein conversion suggests risk of bighorn sheep (Ovis canadensis) to transmissible spongiform encephalopathies: BMC Veterinary Research, v. 9, no. 1, p. 157-167, accessed at https://doi.org/10.1186/1746-6148-9-157. 


\section{Prions in Plants: Defining the Risks}

Since its discovery in Colorado in the late 1960s, CWD has spread widely across North America and continues to increase in prevalence in endemic regions, making eradication and (or) control of the disease challenging, if not unfeasible (U.S. Geological Survey, 2016). Additionally, the extreme environmental stability of the causative prion agent is thought to contribute to accumulating CWD infectivity on the landscape, inevitably exposing other species. One possibility is that plants may serve as a route for CWD disease transmission to wildlife, domestic species, and humans. Previous experiments have provided evidence that plants can accumulate infectious prions that are capable of causing disease in mammalian hosts (Carlson, 2013; Pritzkow and others, 2015). This study will expand on these initial studies by characterizing the mechanism(s) of (1) prion uptake by plants, (2) prion persistence and fate within plant tissues, and (3) prion bioavailability in a variety of plants commonly consumed by cervids. Results from these studies will help to define the risk of plants as reservoirs for CWD disease transmission to wildlife, domestic species, and humans.

\section{Collaborator}

University of Wisconsin-Madison

\section{Contact}

Christopher Johnson, USGS Office of Science Quality and Integrity, cjjohnson@usgs.gov

\section{Publication}

Carlson, C.M., 2013, Environmental prion transmission-Identifying novel disease dissemination routes: Madison, Wis., University of Wisconsin, Ph.D. dissertation, 207 p.

\section{Development of Chronic Wasting Disease Surveillance and Mitigation Tools}

\section{A Broad-Spectrum In Vitro Assay for the Detection and Characterization of Prion Diseases}

The goal of this project is the development of a broad-spectrum ante mortem test for CWD that would allow early, rapid detection of disease in living hosts as well as sensitive and quantitative detection of environmental CWD contamination. Voles appear to be "universal acceptors" of prion diseases (Watts and others, 2014), therefore vole tissues will be used to develop a protein-misfolding cyclic amplification (PMCA) method for prion detection. The broad-spectrum nature of the assay envisioned offers advantages over other PMCA procedures because this assay may have utility for detection of other prion diseases beyond CWD (Nemecek and others, 2013). Early detection of CWD in cervids would be a critical asset in preventing spread of CWD by giving wildlife and natural resource managers the ability to remove positive cases from wild populations earlier, administer potential treatments, or apply other appropriate management strategies. Sensitive and quantitative detection of CWD in the environment would allow determination of (1) environmental reservoirs for CWD infectivity, (2) role(s) the environment plays in transmission of disease, and (3) the environmental exposure risk to known and potential hosts.

\section{Collaborators}

Wisconsin Department of Natural Resources

U.S. Food and Drug Administration

\section{Contact}

Christopher Johnson, USGS Office of Science Quality and Integrity, cjjohnson@usgs.gov 


\section{Publication}

Nemecek, J., Nag, N., Carlson, C.M., Schneider, J.R., Heisey, D.M., Johnson, C.J., Asher, D.M., and Gregori, L., 2013, Red-backed vole brain promotes highly efficient in vitro amplification of abnormal prion protein from macaque and human brains infected with variant Creutzfeldt-Jakob disease agent: PLoS ONE, v. 8, no. 10, 11 p., accessed at https://doi.org/10.1371/journal.pone.0078710.

\section{Degradation of Prions by a Serine Protease from Lichens}

Few biological systems have been identified that degrade the transmissible spongiform encephalopathy (TSE)-associated form of the prion protein $\left(\mathrm{PrP}^{\mathrm{TSE}}\right)$ and reduce PrPT ${ }^{\mathrm{TSE}}$ infectivity. Stability of the TSE agent allows scrapie and CWD agents to persist in the environment for years and cause disease in naïve hosts (Pedersen and others, 2010). Critical to controlling disease transmission is the identification of naturally occurring or engineered agents that can inactivate prions in the environment or in TSE-infected hosts. Previous research found that extracts of at least 40 species of lichens are capable of degrading PrP ${ }^{\text {TSE }}$ under mild conditions. Extracts of protease-positive lichen species can reduce TSE infectivity by treating infected brain homogenate with lichen extracts and examining infectivity in mice (Bennett and others, 2012). Extracts of the protease-positive species Parmelia sulcata, Cladonia rangiferina, and Lobaria pulmonaria diminished TSE infectious titer by approximately three log units. Furthermore, when mice were fed P. sulcata and orally challenged with Rocky Mountain Laboratory (RML) mouseadapted scrapie strain, there was a delayed onset of clinical signs and reduced disease attack rate compared to a proteasenegative lichen species or control. Efforts are currently underway to both better understand the mechanism by which some lichens can protect mice from prion disease as well as to isolate and identify the anti-prion protease from lichens.

\section{Collaborator}

University of Wisconsin-Madison

\section{Contact}

Christopher Johnson, USGS Office of Science Quality and Integrity, cjjohnson@usgs.gov

\section{Publications}

Bennett, J.P., Rodriguez, C.M., and Johnson, C.J., 2012, Prion protein degradation by lichens of the genus Cladonia: The Lichenologist, v. 44, no. 4, p. 523-531, accessed at https://doi.org/10.1017/S0024282912000102.

Johnson, C.J., Bennett, J.P., Biro, S.M., Duque-Velasquez, J.C., Rodriguez, C.M., Bessen, R.A., and Rocke, T.E., 2011, Degradation of the disease-associated prion protein by a serine protease from lichens: PLoS ONE, v. 6, no. 5, 12 p., accessed at https://doi.org/10.1371/journal.pone.0019836.

Rodriguez, C.M., Bennett, J.P., and Johnson, C.J., 2012, Lichens-Unexpected anti-prion agents?: Prion, v. 6, no. 1, p. 11-16, accessed at https://doi.org/10.4161/pri.6.1.17414.

\section{Development of Protein Misfolding Cyclic Amplification (PMCA) for Detection of Chronic Wasting Disease Prions in Environmental Samples and Deer Tissues}

The objective of this research was to develop highly sensitive PMCA methods for testing soil and animal secretions and excreta for the presence of prions, specifically CWD. This study supplemented funding from the National Science Foundation to develop PMCA methods for prion detection in deer secretions and excreta (feces and other tissues). This project resulted in an extension of the PMCA methods for detecting CWD prions in deer secretions and excreta, providing a crucial tool for efficiently measuring the presence of prions in animal and environmental samples (Johnson and others, 2012). PMCA methods using microplates (mPMCA) were tested and implemented in related research to detect CWD in environmental samples. The mPMCA methods were shown to be much more sensitive than the original approach and required less substrate (mouse brain), making the test considerably more efficient. 


\section{Collaborator}

Joel Pedersen, Department of Soil Science, University of Wisconsin-Madison

\section{Contact}

Michael D. Samuel (retired), Wisconsin Cooperative Wildlife Research Unit, mdsamuel@wisc.edu

\section{Publication}

Johnson, C.J., Aiken, J.M., McKenzie, D., Samuel, M.D., and Pedersen, J.A., 2012, Highly efficient amplification of chronic wasting disease agent by protein misfolding cyclic amplification wit beads (PMCAb): PLoS ONE, v. 7, no. 4, 7 p., accessed at https://doi.org/10.1371/journal.pone.0035383.

\section{Antemortem Detection of Chronic Wasting Disease Prions in Nasal Brush Collections and Rectal Biopsy Specimens from White-Tailed Deer by Real-Time Quaking-Induced Conversion}

The expansion of CWD disease makes the development of sensitive diagnostic assays and antemortem sampling techniques crucial for the mitigation of spread. This is especially true in cases of relocation or reintroduction of farmed or free-ranging deer and elk, or surveillance studies in private or protected herds where depopulation is not preferable. This study sought to evaluate the sensitivity of the real-time quaking-induced conversion (RT-QuIC) assay using recto-anal mucosa associated lymphoid tissue (RAMALT) biopsies and nasal brush samples collected antemortem from farmed white-tailed deer $(n=409$; Haley and others, 2016). Antemortem findings were then compared to results from ante- and postmortem samples (RAMALT, brainstem and medial retropharyngeal lymph nodes) evaluated using the current gold standard in vitro assay, immunohistochemistry (IHC). The hypothesis was that the sensitivity of RT-QuIC would be comparable to IHC in antemortem tissues and would correlate with both genotype and stage of clinical disease. The results showed that RAMALT testing by RT-QuIC had the highest sensitivity (69.8 percent) when compared to postmortem testing, with a specificity of greater than 93.9 percent (Haley and others, 2016). These data suggest that RT-QuIC, like IHC, is an effective assay for detection of $\mathrm{PrP}^{\mathrm{CWD}}$ in rectal biopsies and other antemortem samples, and with further research to identify more sensitive tissues, bodily fluids, or experimental conditions, it has the potential for large-scale and rapid automated testing for CWD diagnosis.

\section{Collaborators}

Kansas State University

National Veterinary Service Laboratories

National Animal Disease Center

\section{Contact}

W. David Walter, Pennsylvania Cooperative Fish and Wildlife Research Unit, wdw12@psu.edu

\section{Publication}

Haley, N.J., Siepker, C., Walter, W.D., Thomsen, B.V., Greenlee, J.J., Lehmkuhl, A.D., and Richt, J.A., 2016, Antemortem detection of chronic wasting disease prions in nasal brush collections and rectal biopsies from white-tailed deer by real time quaking-induced conversion: Journal of Clinical Microbiology, v. 54, no. 4, p. 1108-1116, accessed at https://doi.org/10.1128/JCM.02699-15. 


\section{Improving Wildlife Disease Surveillance Using Epidemiological Knowledge}

Numerous situations exist where it is important to determine whether CWD or another wildlife disease is present in a free-ranging population. However, adequate disease surveillance can be labor-intensive and expensive, and there is substantial motivation to conduct surveillance as efficiently as possible. Surveillance is commonly based on the assumption of a simple random sample (Walsh and Miller, 2010), but this can almost always be improved if there is auxiliary information available about disease risk factors. A Bayesian approach to disease surveillance, when auxiliary risk information is available, was created, which will generally allow for substantial improvements in efficiency over simple random sampling (Heisey and others, 2014). Others have similarly employed risk weights in surveillance (Walsh and Miller, 2010), but this can result in overly optimistic statements regarding freedom from disease due to the inability to account for the uncertainty in the auxiliary information. The Bayesian approach remedies this problem and was compared to a published example of risk weights applied to CWD in deer in Colorado (Walsh and Miller, 2010). Methods also were presented that can be used to examine when failing to account for the uncertainty in the auxiliary information has a serious impact on the risk weights approach (Heisey and others, 2014). The Bayesian approach allows a rigorous, "apples-to-apples" comparisons of heterogeneous samples and can significantly improve efficiency of disease detection efforts.

\section{Contact}

Daniel P. Walsh, USGS National Wildlife Health Center,dwalsh@usgs.gov

Robin E. Russell, USGS National Wildlife Health Center, rerussell@usgs.gov

\section{Publication}

Heisey, D.M., Jennelle, C.S., Russell, R.E., and Walsh, D.P., 2014, Using auxiliary information to improve wildlife disease surveillance when infected animals are not detected-A Bayesian approach: PLoS ONE, v. 9, no. 3, 9 p. [Also available at https://doi.org/10.1371/journal.pone.0089843.]

\section{Developing a Surveillance System for Early Detection of Chronic Wasting Disease for Shenandoah National Park}

Management agencies can be faced with emerging wildlife diseases that threaten important wildlife resources. The ability to conduct surveillance for early detection of these diseases is critical to be able to quickly and effectively apply disease management actions should introduction of the disease occur. Despite this need for surveillance activities, budgets can be limited and therefore efficient surveillance systems are paramount. A Bayesian-weighted surveillance system was employed for early detection of CWD in Shenandoah National Park (Jennelle and others, 2018). The disease has been detected in close proximity to the park, which contains high densities of white-tailed deer, and therefore, it represents a clear and present danger to a highly valued wildlife resource within the park. No CWD-positive deer were detected using this system despite sampling and diseasetesting of 70 deer (21 adult males and 49 adult females). Given the lack of disease detection and the sampling effort, if CWD were present in Shenandoah National Park, it was estimated that there is a 95 percent probability the mean prevalence would be less than $0.10,0.043$, and 0.032 for adult males, adult females, and yearling males, respectively. The surveillance system incorporated prior knowledge about CWD with live-sampling of animals to provide a critical baseline assessment of the disease status of the park's deer herd and inform management direction.

\section{Collaborators}

National Park Service

Virginia Department of Inland Game and Fisheries

Wisconsin Department of Natural Resources

\section{Contacts}

Daniel P. Walsh, USGS National Wildlife Health Center, dwalsh@usgs.gov

W. Mark Ford, USGS Virginia Cooperative Fish and Wildlife Research Unit,wford@usgs.gov 


\section{Publication}

Jennelle, C.S., Walsh, D.P., Samuel, M.D., Osnas, E.E., Rolley, R., Langenberg, J., Powers, J.G., Monello, R.J., Demarest, E.D., Gubler, R., and Heisey, D.M., 2018, Applying a Bayesian weighted surveillance approach to detect chronic wasting disease in white-tailed deer: Journal of Applied Ecology, v. 55, no. 6, p. 2944-2953, accessed at https://doi.org/10.1111/1365-2664.13178.

\section{Leveraging Expert Knowledge to Improve Surveillance Strategies for Chronic Wasting Disease}

In 2008, an expert workshop was held in Estes Park, Colorado, to develop a set of management options for wildlife agencies seeking to build scientifically rigorous and cost-effective surveillance and monitoring programs for CWD or refine their existing programs. Experts identified potential demographic and spatial risk factors of susceptible wildlife populations that may be exploited for CWD surveillance and monitoring. Methods for enhancing efforts to detect CWD on the landscape where it is not presently known to exist were examined with a focus on the efficiency and cost-effectiveness of the surveillance program (Walsh, 2012). They also identified means of designing programs to monitor CWD once it is discovered within a jurisdiction.

\section{Collaborators}

National Park Service

Wisconsin Department of Natural Resources

Michigan Department of Natural Resources

Colorado Division of Wildlife

U.S. Department of Agriculture, Animal and Plant Health Inspection Service (APHIS)

\section{Contacts}

Daniel P. Walsh, USGS National Wildlife Health Center,dwalsh@usgs.gov

David L. Otis (retired), USGS Iowa Cooperative Fish and Wildlife Research Unit

Michael D. Samuel (retired), USGS Wisconsin Cooperative Fish and Wildlife Research Unit

\section{Publication}

Walsh, D.P., ed., 2012, Enhanced surveillance strategies for detecting and monitoring chronic wasting disease in free-ranging cervids: U.S. Geological Survey Open-File Report 2012-1036, 42 p. [Also available at http://pubs.usgs.gov/of/2012/1036/.]

\section{Seeded Amplification of Chronic Wasting Disease Prions from Elk by Real-Time Quaking- Induced Conversion}

The expansion of CWD across North America, the Republic of Korea, and Norway makes the development of sensitive diagnostic assays and antemortem sampling techniques crucial for the mitigation of spread (Sohn and others, 2002; Evans and others, 2014; Benestad and others, 2016). This is especially true in cases of relocation, reintroduction, or prevalence studies in large or protected herds where depopulation may be contraindicated. This study sought to evaluate the sensitivity of the realtime quaking-induced conversion (RT-QuIC) assay in rectal mucosal associated lymphoid tissue (RAMALT) biopsies and nasal brushings collected antemortem (Haley and others, 2016). Antemortem findings were then compared to results from ante- and postmortem samples evaluated using immunohistochemistry (IHC). RAMALT samples were collected from populations of farmed and free-ranging Rocky Mountain elk $(n=316)$, with nasal brushes collected from a subpopulation of these animals $(n=205)$. The hypothesis was that the sensitivity of RT-QuIC would be comparable to IHC in RAMALT and would correspond to IHC of postmortem tissues. RAMALT sensitivity (77.3 percent) was found to be highly correlative between RT-QuIC and IHC. Sensitivity was lower when testing nasal brushings (34 percent), although both RAMALT and nasal brush sensitivities were highly dependent on both PRNP genotype and disease progression determined by the obex score. These data suggest that RT-QuIC, like IHC, is a relatively sensitive assay for detection of CWD prions in RAMALT biopsies and other antemortem samples, and with further investigation has potential for large scale and rapid automated testing for CWD. 


\section{Collaborators}

Kansas State University

Colorado State University

National Veterinary Service Laboratories

Canadian Food Inspection Agency

Rocky Mountain Laboratories

National Park Service

\section{Contact}

W. David Walter, Pennsylvania Cooperative Fish and Wildlife Research Unit,wdw12@psu.edu

\section{Publication}

Haley, N.J., Siepker, C., Hoon-Hanks, L.L., Mitchell, G., Walter, W.D., Manca, M., Monello, R.J., Powers, J.G., Wild, M.A., Hoover, E.A., Caughey, B., and Richt, J., 2016, Seeded amplification of chronic wasting disease prions in nasal brushings and recto-anal mucosal associated lymphoid tissues from elk by real-time quaking-induced conversion: Journal of Clinical Microbiology, v. 54, no. 1, p. 1117-1126, accessed at https://doi.org/10.1128/JCM.02700-15.

\section{Assessment of White-Tailed Deer Genetic Structure to Determine Potential Disease Transmission Pathways and Population Susceptibility to Chronic Wasting Disease}

CWD has recently been identified in captive and free-ranging white-tailed deer populations (Odocoileus virginianus) in parts of West Virginia, Virginia, Maryland, and Pennsylvania (Evans and others, 2014). Infectious CWD prions can be spread via direct animal contact or indirectly through the environment. Predictive models that incorporate population connectivity (dispersal) and environmental factors (topology and land cover) would allow managers to identify potential movement and dispersal of white-tailed deer and subsequently mitigate the potential spread of CWD throughout the region. Measuring demographic connectivity presents a challenge to these efforts as it is often difficult to get estimates of dispersal rates, particularly at regional scales. We measured patterns of genetic population structure using 11 microsatellite markers in order to infer patterns of regional population connectivity for white-tailed deer (fig. 6; Miller and others, 2019). We collected 720 tissue samples from 2014 to 2017 over a sampling area that encompassed Pennsylvania, Maryland, and Virginia (approximately $25,000 \mathrm{~km}^{2}$ ). Sex, age, and harvest location were recorded in order to relate genetic population structure to demographic and environmental factors which may control dispersal. Additionally, the genotype of each deer was tested for known singlenucleotide polymorphisms in the prion-protein-gene related to disease susceptibility (Miller and Walter, 2019). The goal was to use these data to identify landscape characteristics controlling deer dispersal, identify potential transmission pathways, and assess population susceptibility to CWD.

\section{Collaborators}

Virginia Department of Game and Inland Fisheries

Maryland Department of Natural Resources

Pennsylvania Game Commission

\section{Contact}

W. David Walter, Pennsylvania Cooperative Fish and Wildlife Research Unit, wdw12@psu.edu

\section{Publications}

Evans, T.S., Schuler, K.L., and Walter, W.D., 2014, Surveillance and monitoring of white-tailed deer for chronic wasting disease in the northeastern United States: Journal of Fish and Wildlife Management, v. 5, no. 2, p. 387-393, accessed at https://doi.org/10.3996/032014-JFWM-021. 
Miller, W.L., Edson, J., Pietrandrea, P., Miller-Butterworth, C., and Walter, W.D., 2019, Identification and evaluation of a core microsatellite panel for use in white-tailed deer (Odocoileus virginianus): BMC Genetics, v. 20, no. 49, 14 p., accessed at https://doi.org/10.1186/s12863-019-0750-z.

Miller, W.L., and Walter. W.D., 2019, Spatial heterogeneity of prion gene polymorphisms in an area recently infected by chronic wasting disease: Prion, v. 13, no. 1, p. 65-76, accessed at https://doi.org/10.1080/19336896.2019.1583042.

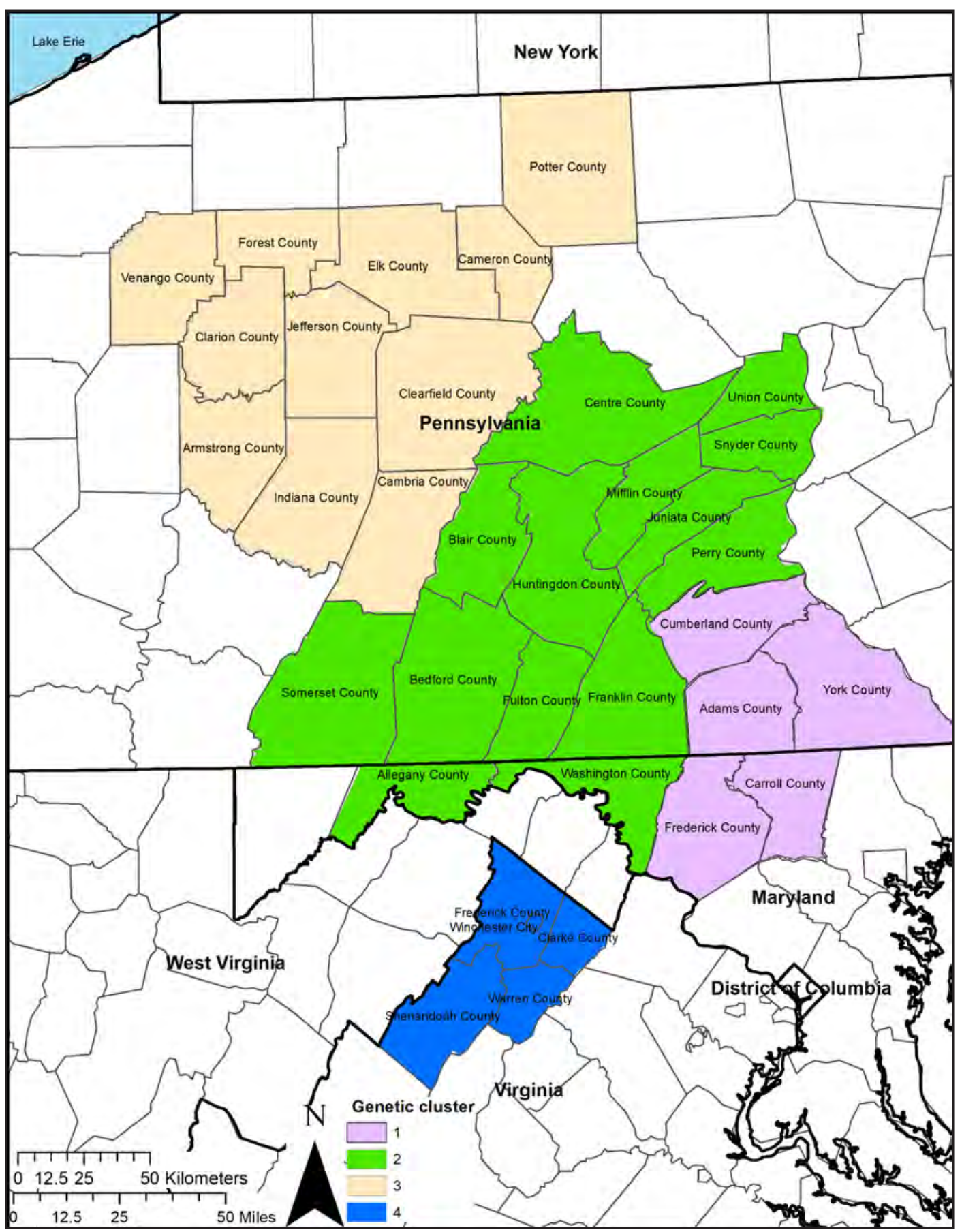

Figure 6. Distribution of white-tailed deer genetic clusters in Pennsylvania, Maryland, and Virginia in the Mid-Atlantic region of the Unites States (Miller and others, 2019). Each color corresponds to a unique genetic cluster inferred from preliminary assessments of subpopulation structure using a genetic distance-based hierarchical clustering algorithm. Light-gray lines are county boundaries. 


\section{References Cited}

[Chronic Wasting Disease Task Force], 2002, Plan for assisting States, Federal Agencies, and Tribes in managing chronic wasting disease in wild and captive cervids: [white paper hosted by the Chronic Wasting Disease Alliance], 20 p., accessed October 31, 2019, at http://cwd-info.org/implementation-document-for-national-cwd-plan-available/.

Benestad, S.L., Mitchell, G., Simmons, M., Ytrehus, B., and Vikøren, T., 2016, First case of chronic wasting disease in Europe in a Norwegian free-ranging reindeer: Veterinary Research, v. 47, no. 1, p. 88, accessed at https://veterinaryresearch. biomedcentral.com/articles/10.1186/s13567-016-0375-4.

Edmunds, D.R., Kaufmann, M.J., Schumaker, B.A., Lindzey, F.G., Cook, W.E., Kreeger, T.J., Grogran, R.G., and Cornish, T.E., 2016, Chronic wasting disease drives population decline of white-tailed deer: PLoS ONE, v. 11, no. 8, 19 p., accessed at https://doi.org/10.1371/journal.pone.0161127.

Finnish Food Authority, 2019, Chronic wasting disease (CWD) and other TSE diseases in cervids: Finnish Food Authority web page, accessed at https://www.ruokavirasto.fi/en/farmers/animal-husbandry/animal-health-and-diseases/animal-diseases/ wildlife/chronic-wasting-disease-cwd-in-cervids/.

Georgsson, G., Sigurdarson, S., and Brown, P., 2006, Infectious agent of sheep scrapie may persist in the environment for at least 16 years: Journal of General Virology, v. 87, no. 12, p. 3737-3740, accessed at https://doi.org/10.1099/vir.0.82011-0.

Gillin, C.M., and Mawdsley, J.R., eds., 2018, AFWA technical report on best management practices for surveillance, management and control of chronic wasting disease: Association of Fish and Wildlife Agencies, Washington D.C., 111 p., accessed at https://www.fishwildlife.org/application/files/9615/3729/1513/AFWA_Technical_Report_on_CWD_BMPs_FINAL.pdf.

Grear, D.A., Samuel, M.D., Scribner, K.T., Weckworth, B.V., and Langenberg, J.A., 2010, Influence of genetic relatedness and spatial proximity on chronic wasting disease infection among female white-tailed deer: Journal of Applied Ecology, v. 47, no. 3, p. 532-540, accessed at https://doi.org/10.1111/j.1365-2664.2010.01813.x.

Hastings, A., Cuddington, K., Davies, K.F., Dugaw, C.J., Elmendorf, S., Freestone, A., Harrison, S., Holland, M., Lambrinos, J., Malvadkar, U., Melbourne, B.A., Moore, K., Taylor, C., and Thomson, D., 2005, The spatial spread of invasions-New developments in theory and evidence: Ecology Letters, v. 8, no. 1, p. 91-101, accessed at https://doi.org/10.1111/j.14610248.2004.00687.x.

Keane, D.P., Barr, D.J., Bochsler, P.N., Hall, S.M., Gidlewski, T., O’Rourke, K.I., Spraker, T.R., and Samuel, M.D., 2008, Chronic wasting disease in a Wisconsin white-tailed deer farm: Journal of Veterinary Diagnostic Investigation, v. 20, no. 5, p. 698-703.

Kim, T.Y., Shon, H.J., Joo, Y.S., Mun, U.K., Kang, K.S., and Lee, Y.S., 2005, Additional cases of chronic wasting disease in imported deer in Korea: The Journal of Veterinary Medical Science, v. 67, no. 8, p. 753-759.

Miller, M.W., and Williams, E.S., 2003, Prion disease-Horizontal prion transmission in mule deer: Nature, v. 425, p. 35-36.

Miller, M.W., Williams, E.S., Hobbs, N.T., and Wolfe, L.L., 2004, Environmental sources of prion transmission in mule deer: Emerging Infectious Diseases, v. 10, no. 6, p. 1003-1006, accessed at https://wwwnc.cdc.gov/eid/articles/issue/10/6/table-ofcontents.

Miller, M.W., Swanson, H.M., Wolfe, L.L., Quartarone, F.G., Huwer, S.L., Southwick, C.H., and Lukacs, P.M., 2008, Lions and prions and deer demise: PLoS ONE, v. 3, no. 12, 7 p.

National Academies of Sciences, Engineering, and Medicine, 2017, Revisiting brucellosis in the greater Yellowstone area: Washington, D.C., The National Academies Press, 209 p. [Also available at https://doi.org/10.17226/24750.]

National Veterinary Institute, 2019, Map of chronic wasting disease (CWD): National Veterinary Institute web page, accessed at https://www.sva.se/en/animal-health/wildlife/map-of-chronic-wasting-disease-cwd.

Pedersen, J.A., and Somerville, R., 2012, Why and how are TSEs sometimes spread via environmental routes?, in Deslys, J.P., Pocchiari, M., Reisner, D., and Somerville, R., eds., Decontamination of prions: Dusseldorf University Press, Dusseldorf, Germany, p. 19-37. 
Pritzkow, S., Morales, R., Moda, F., Khan, U., Telling, G.C., Hoover, E. and Soto, C., 2015, Grass plants bind, retain, uptake, and transport infectious prions: Cell reports, v. 11, no. 8, p. 1168-1175.

Prusiner, S.B., 1982, Novel proteinaceous infectious particles cause scrapie: Science, v. 216, p. 136-144.

Sawyer, H., Hayes, M., Rudd, B., and Kauffman., M.J., 2014, The Red Desert to Hoback mule deer migration assessment: Wyoming Migration Initiative, University of Wyoming, Laramie, Wyoming, 52 p.

Sohn, H.J., Kim, J.H., Choi, K.S., Nah, J.J., Joo, Y.S., Jean, Y.H., Ahn, S.W., Kim, O.K., Kim, D.Y., and Balachandran, A., 2002, A case of chronic wasting disease in an elk imported to Korea from Canada: The Journal of Veterinary Medical Science, v. 64, no. 9 , p. $855-858$.

U.S. Geological Survey, 2016, Map of chronic wasting disease in North America: U.S. Geological Survey web page, accessed at http://www.nwhc.usgs.gov/disease_information/chronic_wasting_disease/index.jsp.

Walsh, D.P., and Miller, M.W., 2010, A weighted surveillance approach for detecting chronic wasting disease foci: Journal of Wildlife Diseases, v. 46, no. 1, p. 118-135, accessed at https://doi.org/10.7589/0090-3558-46.1.118.

Watts, J.C., Giles, K., Patel, S., Oehler, A., DeArmond, S.J., and Prusiner, S.B., 2014, Evidence that bank vole PrP is a universal acceptor for prions: PLoS Pathogens, v. 10, no. 4, 14 p., accessed at https://doi.org/10.1371/journal.ppat.1003990.

Williams, E.S., and Young, S., 1980, Chronic wasting disease of captive mule deer-A spongiform encephalopathy: Journal of Wildlife Diseases, v. 16, no. 1, p. 89-98.

Wisconsin Department of Natural Resources, 2019, CWD prevalence trends: Wisconsin Department of Natural Resources Wildlife Habitat web page, accessed at https://dnr.wi.gov/topic/wildlifehabitat/prevalence.html.

Wisconsin Legislative Audit Bureau, 2006, An evaluation —Chronic wasting disease: State of Wisconsin Department of Natural Resources Report 06-13, 88 p., accessed at http://legis.wisconsin.gov/lab/reports/06-13full.pdf.

Wyoming Game and Fish Department, 2013, Casper region—Annual big game herd unit reports: Casper, Wyoming, p. 176-177. 

For more information concerning the research in this report, contact: Anne Kinsinger

USGS Associate Director for Ecosystems

703-648-4050

akinsinger@usgs.gov

M. Camille Hopkins

USGS Wildlife Disease Coordinator

703-648-4019

mchopkins@usgs.gov

Publishing support provided by the U.S. Geological Survey Science Publishing Network, Reston and Sacramento Publishing Service Centers

Edited by David A. Shields

Layout by Kimberly Engelking 


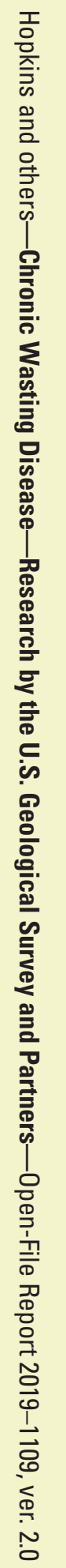

